\title{
III. La VidA Cotidiana en el Convento Dominico de Cartagena
}

\section{El régimen disciplinario}

\begin{abstract}
Algunos de los historiadores de la Orden de Predicadores coinciden en afirmar que en el horizonte de los conventos y casas fundadas en el Nuevo Reino de Granada, el Convento San José de Cartagena descolló entre los demás por la indisciplina de sus frailes. La gran crónica inédita del padre fray Enrique Báez Arenales, titulada La Orden Dominicana en Colombia, recopila en su Arcano (el volumen ocho de la colección) algunos de los acontecimientos, a su juicio, más vergonzosos. Aquellos episodios de inobediencia religiosa, dice fray Enrique, deben exponerse, pues "la historia es historia y no apología o adulación de nadie" (Báez, s.f. [vol. 8], p. 416) ${ }^{1}$. Entre los sucesos más resonantes ocurridos en Cartagena, destaca la rebelión dirigida en 1550 por fray Andrés Albis, el dominico que, según relata Juan de Castellanos en sus Elegías, "viéndose Señor del Monasterio, quiso ser Monarca del Imperio"
\end{abstract}

1 De hecho, Báez critica la "falta de honradez" de fray Alonso de Zamora por "callar" acerca de estos casos. 
(1852, p. 428)². También la tropelía con los Franciscanos en 1756 por el presidio del padre Manuel Villar ${ }^{3}$.

Para finales del siglo XVIII, en las cartas y otras comunicaciones (oficiales y privadas) de varios de los prelados y visitadores del Claustro cartagenero, ciertamente se aprecia el malestar por la relajación de las costumbres entre los frailes dominicos. La indisciplina religiosa había tomado relevancia para el Estado español a causa de las reformas fiscales y administrativas de los Borbones, puesto que todas las instancias generadoras de rentas, como el clero regular y secular, debían sujetarse a esta nueva regulación económica (Lynch, 1983, pp. 7-10). A través de los informes realizados por los visitadores de los conventos en todas las colonias españolas en América hacia la segunda mitad del siglo XVIII, la Corona tuvo conocimiento del estado de las cuentas y de la disciplina (o, en su defecto, la relajación de las costumbres) de las órdenes religiosas (Burns, 2008, pp. 216, 217).

Según estos informes, avalados, a su vez, por las autoridades civiles y eclesiásticas, el Estado intentó secularizar las doctrinas y los curatos en manos de los regulares bajo el supuesto de imprimirle mayor eficiencia al proceso de evangelización y a la administración de las rentas producidas por esta actividad. Sin embargo, las diferentes órdenes conventuales opusieron resistencia y lograron dilatar esta política, en gran medida, al estipular que entregarían paulatinamente las misiones o curatos hasta que muriesen o enfermasen los frailes asignados en estos lugares (Plata, 2012, pp. 181-185).

$2 \mathrm{Al}$ padre Albis se le atribuye el liderazgo en el "alboroto de los frailes" —llamado así por su participación y la de otro dominico de nombre Alonso-, un intento de rebelión contra el adelantado Pedro de Heredia. Según parece, en esta conspiración estuvieron involucrados algunos exsoldados de Gonzalo Pizarro, artífice de la rebelión de los encomenderos del Perú, quienes se levantaron en protesta contra las "Leyes Nuevas" dictadas en 1542. El plan contemplaba el asesinato del gobernador Heredia y otras gentes principales de Cartagena, durante una función religiosa en la que el dominico Albis debía hacer la "señal de degüello desde el púlpito". Tras rebelarse los planes, muchos de los implicados fueron ajusticiados, excepto fray Andrés y fray Alonso, a quienes por "respeto a las órdenes sagradas", solo se les condenó al destierro en España. El padre Albis murió ahogado en La Habana, cuando trató de fugarse bajando por las cadenas del ancla del navío en el que los conducían a la Península (Acosta, 1848, p. 324).

3 El padre Villar pertenecía a la religión de San Francisco. Por varias confrontaciones — que llegaron a los golpes - con el Síndico y el padre Guardián de su Convento, el Provisor del Obispado lo condenó a ser puesto preso en el Claustro de los dominicos. Según parece, toda la comunidad de Padres Predicadores condujo al reo a uno de los interrogatorios atado de pies y manos con grilletes, lo que ocasionó gran molestia entre los franciscanos, dando lugar a que ambas religiones se increparan mutuamente con "palabras muy ofensivas y afrentosas, escandalizando la ciudad” (Báez, s.f., [vol. 8], p. 457). 
En este contexto, el visitador de los conventos de la Costa, fray Juan Antonio Buenaventura y Castillo, dictó un completo plan para desterrar para siempre la indisciplina en 1788. Según el padre Buenaventura, por la "profesión" que solemnemente hacía cada uno de los religiosos de Santo Domingo, cada uno, sin excepción de persona ni tiempo, estaba obligado a "la observancia del método y orden de las horas canónicas, la fijeza en los actos literarios, el recogimiento monástico y la continua asistencia al coro, confesonario, refectorio y otros actos de religión" (Archivo de la Provincia Dominicana de Colombia (en adelante APDC), 1788b, f. 3$)^{4}$.

En comunicación al prior Pedro José Rossi, el Visitador ordenó, entre otros asuntos, que para no perturbar jamás "el orden y el régimen de los estudios", se debían determinar claramente los horarios de las oraciones. Para ello recomendaba que la prima (en la primera parte del día) se cantara a partir de las seis de la mañana, excepto los días festivos cuando se correría a las ocho, empezando con la misa conventual. La nona, sobre las tres de la tarde, siempre debía decirse después de tomar el refresco correspondiente, menos los días de guardar ayuno. Las completas (la oración para agradecer por el día que termina) se debían rezar en la iglesia a las cuatro y media de la tarde. En seguida se cantaba el salve y se rezaba el Rosario por toda la comunidad ${ }^{5}$, aunque

4 La visita del padre Buenaventura tenía, además, el propósito de recabar en los conventos y en otras corporaciones civiles y eclesiásticas de las gobernaciones de Cartagena y Santa Marta donativos para financiar la reconstrucción del templo y claustro de Nuestra Señora del Rosario de Santafé, severamente dañados por el terremoto de julio de 1785. El 8 de enero de 1789, el padre Juan Antonio dirigió una nota al Teniente de Gobernador y al señor Provisor Eclesiástico de Santa Marta, solicitándoles facultades para pedir limosnas destinadas a levantar "lo que tumbó" el sismo. Las notas de petición decían: "Fr. Juan Antonio de Buenaventura, del Sagrado Orden de Predicadores, Visitador de los Conventos contenidos en las Costas de Cartagena y Santa Marta, ante V. S. con el mayor respeto parezco y digo que con motivo de haber experimentado nuestro Convento e Iglesia de la ciudad de Santafé las más lastimosa ruina de junio de 1785, y haber quedado casi sin templo en donde celebrar los Oficios divinos y repartir las saludables doctrinas y no tener con qué continuar la obra que a expensas de algunas limosnas que de los caritativos pechos así del Excmo. e Iltmo. Señor Virrey (Caballero y Góngora), como de otros hemos recibido, y hallarse aquel Convento sumamente necesitado por la escasez de sus rentas y haberse consumido la limosna recibida en levantar la iglesia hasta el estado de entecharse, suplicamos a V.S. su superior licencia para pedir en toda la Provincia la limosna que la caridad de los fieles quiera dar para un fin tan santo y con ella poder continuar una obra acepta a los ojos de Dios y útil al pueblo que en ello recibiremos merced y gracia ella mediante" (citado por Mesanza, 1936, p. 56).

5 Para estimular esta práctica agrega: “este fue el patrimonio (el salve y el rosario) que nos dejó nuestro Santo Patriarca, al cual estamos obligados, así por hijos de nuestro Padre, como por haberse nuestra Religión obligado en tiempo del Beato Jordán por voto a cantar la salve todos los días después de las completas y también por estar concedidas por Paulo V doscientos días de indulgencia” (APDC, 1788b, f. 3v). 
este último, para dar "ejemplo de tierna devoción”, se debía rezar "indispensablemente haciendo cabeza un religioso y no secular alguno" (APDC, 1788b, f. 3v).

Los novicios del Convento bebían rezar en el oratorio dos tercios del rosario a las cinco de la mańana, y hacer luego media hora de oración mental. Después de la misa (ocho de la mañana) hasta tres cuartos para las once, debían estar estudiando en el Claustro. En la noche estudiaban de ocho a nueve, enseguida rezaban el otro tercio del rosario, se les daba la bendición y se les mandaba a acostar, menos cuando tuvieran maitines, los cuales solo se harían de noche para no interrumpir los actos literarios (APDC, 1788b, f. 4). "Por la sospecha de los robos que pudieran hacer quienes vaguean ociosos infiriendo daños en donde hallan ocasión y evitar otros inconvenientes y desórdenes", el Visitador mandó también que la portería se cerrara a las ocho y media de la noche (APDC, 1788b, f. 4v) ${ }^{6}$. Asimismo, previno que los frailes no ingresaran al Claustro (que era un sitio público) sin el hábito y que ninguno saliera solo a la calle sin compañero religioso, por ser una conducta irregular, escandalosa y sospechosa.

Al parecer, a lo largo de los años en el Claustro cartagenero se habían ido dictando algunas dispensas para consumir carnes en días prohibidos y evitar los ayunos. Sin embargo, en cumplimiento de la regla y las constituciones, el Visitador suspendió toda licencia, y ordenó a todos los miembros de la comunidad presentarse ante el prior, para que según las circunstancias y condiciones particulares de cada uno se justificaran y tramitaran de nuevo estos permisos ${ }^{7}$.

Además de las ceremonias religiosas, las cátedras y actos literarios (las lecciones, defensas o sustentaciones) estaban fuertemente permeadas por un riguroso ceremonial. Por ejemplo, el catedrático de física y filosofía, fray Javier Ibáñez, fue suspendido de sus clases por el regente fray José María Pontón, por desatender el orden de entrada a la aulas durante una conclusioncilla. Según fray José María, el padre Ibáńez se quedó fuera de uno de los salones, a pesar de haberlo visto entrar a él. En su defensa, fray Javier argumentó que ni la costumbre ni las constituciones y las leyes de ambos derechos (canónico y civil) establecían nada sobre entrar antes o la par de

6 Esta precaución quizá también se dictó por varios incidentes, como el hurto cometido en la sacristía del templo por un esclavo comprado por el padre fray José Mariano Adminaorta. Al parecer el negro quiso "sonsacarse" una zamba esclava de la casa de los Condes de Santa Cruz de la Torre, a la cual cortejaba con insistencia. Esto dio lugar a una airada réplica por parte de la Condesa. Aunque el padre Adminaorta dijo que vería la forma de vender o sacar el esclavo una vez enterado de sus "malas habilidades", este se dio a la fuga saqueando a los conventuales (APDC, 1770, f. 1).

7 El plan del visitador Buenaventura y Castillo fue apelado por el padre Rossi el 25 de julio de 1789, señalando que las providencias se tomaron sin "su audiencia ni citación", lo que a su juicio podía ser interpretado (sobre todo entre los seculares) como una pena ante un delito que él no había cometido. 
los padres regentes, sino del padre prior y del fraile a quien le correspondiera defender. Como ninguno de estos dos últimos había ingresado al aula, según fray Javier y otros testigos ${ }^{8}$ porque desde la posición en la que estaban podían ver que estos aún no salían de sus celdas, no consideró oportuno ni indispensable entrar tras el padre Pontón (APDC, 1793b, f. 12v)9 .

Probablemente este choque se debiera más al interés del padre Regente de hacer valer su autoridad, pues según los testigos al impartir el castigo a fray Javier dijo en voz alta y enfática que él tenía potestad para imponer esa y otras sanciones, para lo cual, le hizo leer al padre Maestro de estudiantes un capítulo de la constitución en el que se definen los atributos y funciones de los regentes conventuales. Al margen de esa ostentación de poder (recuérdese que además de toda la comunidad de Padres Predicadores, a las defensas podían también asistir público y otros invitados), el episodio nos muestra otras facetas del régimen disciplinar del Convento. En efecto, según reza el expediente, fray Javier fue compelido por el Regente para que le hiciera una venia, pero según dice —acatando la constitución — no se movió de su puesto hasta no ser autorizado por el Prior (APDC, 1793b, f. 13) ${ }^{10}$.

La orden de hacer aquella reverencia (e incluso la suspensión de las lecciones) era quizá una pena menor, pues en orden a la gravedad de las faltas se podía llegar al presidio o al destierro. Además de los casos del fray Andrés Albis (desterrado) y fray Manuel Villar (franciscano puesto preso en el Convento Dominicano), el padre Báez relata que a comienzos de 1785 el Claustro de Cartagena sirvió de "corral" de cuatro frailes en calidad de presos. Los religiosos eran tres dominicos y un franciscano provenientes de la Audiencia de Quito, donde se les acusaba de “ciertas violencias contra Don Antonio Unda, vecino de aquella ciudad" (Báez, s.f. [vol. 8] p. $83)^{11}$. Los dominicos (pues el franciscano se dio a la huida) fueron llevados a España por orden del Rey, a pesar de la vejez y deteriorado estado de salud de uno de ellos.

8 En averiguación de lo ocurrido en este episodio, el padre Rossi mandó preguntar a algunos de los testigos: 1) quiénes y dónde estaban esperando al Prior; 2) si se le pidió al padre Ibáńez entrar al aula y si este se negó o no, y 3) si se tenía por costumbre que el prior entrara primero a las aulas.

9 Según los testigos, en el Claustro Dominico de Cartagena las puertas de las aulas eran tan anchas, que los padres lectores podían entrar todos al mismo tiempo que el prior.

10 Uno de los presentes, fray Agustín Archila, testificó al respecto: "que dicho M.R.P. regente le mandó a hacer la venía al Padre Lector Fr Javier Ibáńez quien vuelto al Padre Prior que estaba en la cátedra le preguntó: ¿hago la venía Padre Prior? Quien respondió: si se la manda hacer el Padre Regente hágala; entonces el Padre Ibáñez la hizo" (APDC, 1793b, f. 13).

11 Se trataba del franciscano Manuel Navarrete y de los padres de la Orden de Predicadores José Garzón, Juan Campusano y José Merino. 


\section{Un fraile inobediente y mercader}

Las comisiones extramuros eran quizá el momento en el que se ponían a prueba con más fuerza el respeto y la fidelidad de los frailes a sus votos. Alejados de la vigilancia de los superiores y de la mirada del resto de la comunidad, los hermanos que temporalmente abandonaban el Claustro para adelantar alguna misión pastoral, un trámite administrativo o cualquier otra diligencia, debían honrar con su conducta los valores de su religión. Aquellos que salían en este tipo de encargos eran designados y autorizados expresamente por el prior del Convento, quien les entregaba una partida para el viático y demás urgencias del camino, de la cual rendían a su regreso información juramentada del modo y el tiempo de su ejecución. Asimismo, si en sus encomiendas hacían cobros o percibían rentas o especies a favor del Convento, los comisionados debían asentar en un libro la relación de los pagos, expresando los nombres de los deudores y las cuantías de los abonos, los saldos y paz y salvos según cada caso. En muchas ocasiones, a estas relaciones los frailes anexaban recibos, constancias y todos aquellos documentos que verificaran su conducta en la administración de los dineros, como quiera que este tipo de encargos evidenciaban tanto la obediencia a los preceptos de la Orden, como su buen nombre y honra personal.

La mayoría de las representaciones y cargos de los frailes para la administración de curatos, el recaudo de arrendamientos, las visitas a otros conventos en las provincias vecinas o al de la capital transcurrían sin mayores sobresaltos. Empero, en el Convento San José de Cartagena tuvo bastante resonancia la causa cursada entre 1795 y 1797, contra fray Tomás López (APDC, 1795-1797, ff. 166-219), a quien se acusó de omisiones y faltantes en la relación de los gastos y las cobranzas efectuadas durante una de esas comisiones. El desajuste en las cuentas quizá no hubiera tenido mayor trascendencia si a manos de las autoridades del Convento no hubiera llegado una relación de pagos y deudas de letra y firma de fray Tomás, la cual evidenciaba que este, contradiciendo flagrantemente su voto de pobreza, se había dedicado a vender ropas o "géneros de castilla" a título propio. A estas imputaciones se vinieron a sumar graves indicios sobre la conducta del fraile, quien no solo trató de desviar y entorpecer las averiguaciones, sino que en repetidas ocasiones desatendió los llamados a esclarecer la situación y, además, respondió de manera airada y descortés a sus superiores en varias cartas y mensajes.

La comisión de fray Tomás López, encargo hecho por el padre prior fray Manuel Ruiz en diciembre de 1794, consistía en fungir como padre procurador en la posesión a nombre de la Orden de Predicadores de la hacienda Los Sábalos y de otras tierras en la región de Santa Cruz de la Guayra, al norte de Cartagena (límite de los actuales departamentos de Bolívar y Atlántico). Los terrenos, transferidos al Convento de San José en 1786, se encontraban ocupados 
por varios aparceros y labradores, quienes pagaban con dinero, especies o trabajo una cuota de arrendamiento. El padre López debía levantar el registro de los arrendatarios, vigilar el cobro de los pagos atrasados, organizar los trabajos para preparar más terrenos de cultivo y componer los caminos y la casa principal de la hacienda.

En principio el reporte del viaje no deja entrever ninguna contingencia o irregularidad. En su relación de gastos y cobranzas, el padre López afirma que desde su salida el 23 de diciembre de 1794, hasta el 15 de mayo del ańo siguiente tuvo a su cuenta su manutención y la de otras cinco personas: don Agustín Tornería, quien lo acompańaba en calidad de juez recaudador; Pedro Pablo Ramírez, cabo de Justicia comisionado como auxiliar de este último, y tres mozos esclavos del Convento, entre ellos un "muchacho" de nombre "Josecito" que hacía las veces de cocinero y sirviente personal del padre. La cuenta diaria de los avíos pagados por el fraile deja entrever la cotidianidad de este tipo de encargos. La compra corría entre pagar los almuerzos y cenas en las hospederías y posadas del camino, el alquiler y la alimentación de las bestias, el lavado de la ropa y la visita periódica a la barbería. Ocasionalmente también se abastecían de víveres (seguramente para cocinar ellos mismos), haciendo anotación día por día de cuánto y en qué se gastaba. El aceite, la manteca y el agua en "limetas" (botellas) y "botijuelas" (vasijas de barro) encabezaban casi siempre la lista, seguidos de los huevos (que se comían a diario), la panela, los plátanos y otros "recados" y especias. Ocasionalmente se agregaba al gasto el chocolate, el arroz — que por entonces se vendía en almudes (cajas de madera) los fideos, el vinagre y el aguardiente. La harina para las hostias, la galleta (pan sin levadura), los bollos, las velas y el jabón constituían los rubros menos frecuentes ${ }^{12}$.

La mayoría de estos gastos (en total 390 pesos, 5 reales y 3 cuartillos) se subvencionaron con los cobros de los arrendamientos de las parcelas. Así, fray Tomás asienta en su informe que cruzando la cuenta de gasto que citamos antes con la cuenta de "Data", las partidas restantes quedaban a favor de la hacienda y por tanto del Convento, aunque no hay que olvidar que no todos los pagos se hacían en dinero, siendo muy comunes las liquidaciones en jornales y especies (animales y cosechas).

Al informe entregado por fray Tomás a las autoridades y superiores del Convento, se adjuntaron varios recibos y notas firmadas para sustentar los gastos. Entre otros, un recibo por 4 pesos del alquiler de una casa en El Palmar de La Candelaria, donde se radicó el Fraile con parte de su comitiva luego de haber caído gravemente enfermo (APDC, 1795-1797, f. 173) ${ }^{13}$; el pago de 10 pesos 2 reales

12 Pieza 1. Relación de gastos y cobranzas de la comisión de Sábalos. Cartagena, 20 de junio de 1795. 13 Pieza 2. Recibo de pago a Santiago Carpintero por el alquiler de una casa, 11 de marzo de 1795. 
por medicinas y visitas del fraile Mariano García de la Orden Hospitalaria de San Juan de Dios (APDC, 1795-1797, f. 175) ${ }^{14}$; el adelanto de 30 pesos de los honorarios de Agustín de Tornería, entregados a su mujer, María Concepción Enamorado (APDC, 1795-1797, f. 177) ${ }^{15}$, y el pago de 4 pesos al cabo Ramírez, designado por el Gobernador y el Teniente General de la Plaza de Cartagena para respaldar las cobranzas (APDC, 1795-1797, f. 180) ${ }^{16}$.

A pesar de las diligentes explicaciones del padre López, los balances de la "comisión de Sábalos" no fueron bien recibidos por el Prior conventual. A juicio del padre fray Manuel Ruiz, además de que los gastos sobrepasaban notoriamente al recaudo, las cuentas eran confusas en muchos apartes, faltaba buena parte de los recibos de los arriendos y, con todo, se le quedaban debiendo a fray Tomás 64 pesos y 2 reales y medio. Para averiguar la causa del saldo negativo y de todas las inconsistencias y faltantes, el prior envió a la hacienda al padre fray Agustín Sánchez en calidad de inspector. Este segundo comisionado debía investigar todas las actuaciones del primero, revisando uno a uno los recibos expedidos a los terrajeros y, además, efectuando él mismo los cobros que quedaran pendientes.

En la relación dada a su regreso, después de jurar la cuantía y naturaleza de sus propios gastos como todos los comisionados (APDC, 1795-1797, ff. 183, 184) 17, fray Agustín mostró que, en efecto, algunos de los campesinos alegaban no habérseles librado los recibos de los pagos, en ciertos casos, porque no tuvieron los reales completos para cubrir la cuota. Otros mostraban sus cuentas con las firmas en regla, tanto del padre Tomás como del recaudador Tornería, y otros más decían haber extraviado el documento (APDC, 1795-1797, ff. 181, 182) ${ }^{18}$. Como pudo verificar el padre Sánchez al efectuar él mismo los cobros, varios de los aparceros a duras penas

14 Cuando al parecer fray Tomás adquirió una "enfermedad en el escroto”. Pieza 5. Recibo de pago a fray Mariano García del Hospital San Juan de Dios, por las medicinas de la botica y las visitas a fray Tomás López del orden de Santo Domingo. Cartagena, 9 de mayo de 1795.

15 Pieza 6. Recibo de pago a María Concepción Enamorado, legítima mujer de don Agustín de Tornería, por las diligencias adelantadas por su marido para el Convento de San José, 15 de marzo de 1785.

16 Pieza 9. Recibo de pago por cuatro pesos al cabo Pedro Pablo Ramírez, por auxiliar en las cobranzas de los terrajeros deudores de las tierras de Sábalos, pertenecientes al Convento de Santo Domingo, 5 de marzo de 1785 .

17 Pieza 11. Razón jurada de los gastos que se han hecho por el P. Fr. Agustín Sánchez comisionado por el muy reverendo padre prelado prior Fr. Manuel Ruiz desde hoy día 28 de abril de 1795 hasta el día 6 de junio del mismo ańo.

18 Pieza 10. Razón de los arrendatarios que presentaron su recibo de pago al P. Fr. Agustín Sánchez. 
cubrían su deuda. Por ejemplo, a José María Cobo, quien ejercía la carpintería, se le debieron tasar como pago varios trabajos en ese ramo (APDC, 1795-1797, f. 185) ${ }^{19}$; a Chana Jiménez facturarle tres de los cuatro pesos que adeudaba; a Lino de la Hoz, cuatro de ocho; a Nicolás de Altamar, dos de tres, y a Luis de Castro recibirle un caballo (APDC, 1795-1797, f. 186) ${ }^{20}$.

Sea como fuere, aún con las pesquisas de fray Agustín persistía la duda sobre el saldo en contra en las cuentas de Sábalos. A finales de 1795, el padre López quiso, según sus propias palabras, "indemnizar su fama de las lenguas envenenadas" (APDC, 1795-1797, f. 187). En carta a fray Juan Antonio de Buenaventura, nuevo prior en el Convento, no solo puso en entredicho las intenciones de fray Manuel Ruiz, sino que pidió que los libros y facturas fueran revisados por un "insigne aritmético", para que así se supiera quién era "el verdadero delincuente o deudor" (APDC, 1795-1797, ff. 187-189) ${ }^{21}$. Afirmaba el acusado que el padre Ruiz, queriendo "pillarlo en algún exceso", no aceptó las cuentas y que incluso llegó a decir que este se "había soplado 300 pesos, por sólo 15 o 20 cargas de casabe que mandó" y "vuelto una fiesta los arrendamientos" (APDC, 1795-1797, ff. 187-189). Además de estas réplicas, fray Tomás impugnó los documentos de la inspección hecha por fray Agustín Sánchez, por tener varias anotaciones con letras distintas y porque las partidas no estaban firmadas ni juramentadas ${ }^{22}$.

Para resolver las dudas planteadas, el prior Buenaventura designó como revisores del caso al padre maestro de estudiantes, fray Javier Ibáńez, y al padre lector de artes, fray Ignacio Díaz. Curiosamente, sobre lo primero que llamaron la atención fue acerca de las diferencias en la cuentas de gastos de uno y otro de los comisionados de Sábalos (los padres Tomás López y Agustín Sánchez), señalando que mientras el primero — para mantenerse él, dos esclavos y el cocinero - gastaba dos reales y medio al día, el segundo "para mantener sólo su persona, gastaba tres" (APDC, 1795-1797, ff. 188, 189) 23.

A la pregunta de por qué las listas de los cobros hechos por el padre Sánchez estaban sin firma y con letras distintas, este arguyó en su defensa que los documentos no eran los originales

19 Pieza 12. Lista de lo que me han pagado a mí, Fr. Agustín Sánchez.

20 Pieza 13. Razón de los sujetos que han pagado los terrajes de Santa Cruz y de la Hacienda Sábalos.

21 Pieza 14. Carta de Fr. Tomás López a Fr. Juan Antonio de Buenaventura prior del Convento de Cartagena. Diciembre 15 de 1795.

22 En efecto, las piezas 12 y 13 del expediente no están firmadas y tienen al menos dos tipos de letra.

23 Pieza 15. Concepto de fray Javier Ibáńez y fray Ignacio Díaz, sobre algunas de las exigencias hechas por fray Tomás López en su carta al prior de Cartagena. 
que él entregó, sino copias dictadas por fray Manuel Ruiz, entonces prior del Convento (APDC, 1795-1797, ff. 190, 191.) ${ }^{24}$. Tras buscar en el archivo los documentos originales, los padres revisores no pudieron encontrar el expediente, sino solamente algunos apuntes sueltos sobre la hacienda.

Mientras tanto, el padre López insistía en su inocencia, pero también en reclamar los casi 70 pesos que se le habían salido a deber. En otra carta al prior Buenaventura de enero de 1796, fray Tomás argumentó que el "alcance" del cargo y descargo de las cuentas obedecía a que se estaban sumando como gastos las raciones (los alimentos) de aquellos que pagaron su deuda con rozas y jornales. Asimismo, explicó que aquello que se le adeudaba correspondía al pan que el Convento no le dio mientras estuvo en esas diligencias; al pago del cirujano que lo atendió en su enfermedad — que lo pagó de su cuenta, cuando siempre le correspondía a la Comunidad velar por la salud de los frailes_-, a la partida que le abonó a la mujer de Agustín de Tornería, y al importe de su procuraduría, "mi trabajo personal -dice- el haber estado cerca de tres meses en un continuo movimiento pasando malos días y peores noches, a fin de cobrar y reparar la Hacienda” (APDC, 1795-1797, f. 193v) ${ }^{25}$. Según conceptuaron los padres revisores Ibáñez y Díaz, las reclamaciones de fray Tomás eran justas, razón por la cual el Prior ordenó a finales de febrero franquearle una orden de pago del depósito del Convento por la suma que exigía.

Un mes más tarde, otro testimonio vino a agitar aún más la polémica. En una carta dirigida al padre Prior a finales de marzo, don Agustín de Tornería, el juez contratado por el Convento para legalizar los cobros y el traspaso de las tierras en Sábalos y Santa Cruz, no solo desmintió las versiones de fray Tomás acerca del gasto diario, sino que puso en entredicho su conducta personal. Por ejemplo, sobre el pago de sus honorarios dice: "vergüenza da ver mi cuenta de lo recibido en picos de dos reales, tres, ocho etc. Más aún al ver que se supongan tantos gastos, cuando con dos huevos por la mañana y otros dos a la tarde, a veces un pedazo de puerco salado, o de carne con un puñado de arroz se me ha mantenido" (APDC, 1795-1797, f. 198) ${ }^{26}$.

Según Tornería, la "estrechez" del padre Procurador en la administración del gasto era mayúscula: no compraba carne a pesar de que se conseguía con facilidad, ni siquiera pescado salado. El único "desengrazo" (postre) eran plátanos, y aún estos les faltaban con frecuencia.

24 Pieza 16. Defensa de fray Agustín Sánchez.

25 Pieza 17. Carta de fray Tomás López al prior fray Antonio Buenaventura, en la cual le aclara las cuentas de su estadía en Sábalos y Santa Cruz. Cartagena, enero 24 de 1796.

26 Pieza 21. Carta de Agustín Tornería al prior del Convento de Cartagena, 28 de marzo de 1795. 
El chocolate lo molía sin canela y apenas daba "bollito y medio para tres pozuelos que era agua y no chocolate" (APDC, 1795-1797, f. 199v). Luego —se pregunta el juez—, “¿dónde están los decantados gastos? ¿Dónde están las viandas exquisitas que el Padre Procurador ha puesto que yo le he pedido?" (APDC, 1795-1797, f. 200). Afirma además que los caballos en los que viajó eran de su propiedad y no de alquiler, y que si el padre López tuvo que pagar por su alimentación fue porque un día se los pidió prestados, sin que hasta la fecha se los hubiera devuelto. Advierte también que de continuar él con el encargo de cobrar los terrajes, lo haría siempre que le entregaran cabalgaduras y los dos reales diarios para su alimentación, y se destinara a otra persona como procurador. Con el padre López — dice finalmente— "no voy ni al cielo, no quiero entenderme más con [él], pues sus máximas solo miran a su utilidad y proyectos, y no al asunto principal" (APDC, 1795-1797, f. 201v).

Durante los meses siguientes, fray Tomás fue destinado al curato del Palmar de la Candelaria y con ello los ánimos se apaciguaron un poco. Sin embargo, con la llegada de fray José María Pontón como visitador del Convento en diciembre de 1796, se reanudó la investigación. Al revisar el estado de las finanzas conventuales, lo primero que llamó la atención del Visitador fue la pérdida del cuaderno original con las cuentas de la comisión en Sábalos y Santa Cruz. Ante la necesidad de verificar dichos gastos y entradas, el padre Pontón interrogó a varios de los frailes sobre el paradero del cartapacio, y aunque casi todos coincidieron en asegurar haberlo visto en una de las gavetas del arca del depósito, este no apareció. Por el contrario, entre los frailes fue cobrando fuerza la versión de que el mismo padre López lo había sustraído de su puesto.

Este hecho suscitó una enérgica comunicación del Visitador, máxime cuando luego se difundió que en el libro de cuentas estaba inserto un auto del padre Ruiz, por el cual le prohibía al padre López administrar curato alguno, lo cual significaba que ejercía como párroco en el Palmar de forma ilegítima. En su comunicación, el padre Pontón le exigió a fray Tomás, "bajo el precepto formal de la obediencia", responder cuanto antes a todo lo que se le preguntara en el cuestionario adjunto. Por ejemplo, las razones por las que sustrajo sin licencia las cuentas del depósito, o por qué en algunos casos facturaba menos de lo que en realidad había recibido (APDC, 1795-1797, f. 202v) ${ }^{27}$. También por qué cargaba al Convento una deuda con Juan Bernardo Ortiz, cuando este individuo no acusaba tal obligación, o por qué había tasado como

27 Entre otros casos, a Juan Alberto Jiménez le recibió 4 pesos, pero en la cuenta puso "nada debe"; a Laureano Carrillo le facturó 7 pesos, habiéndole entregado 8; a Diego Tren lo omitió de las listas, habiéndole recibido 12 pesos. Pieza 22. Carta del Padre visitador Fr. José María Pontón en la que incluye un cuestionario sobre las principales dudas e inconsistencias de las cuentas entregadas por Fr. Tomás López. 
pago la conducción del casabe a Cartagena hecha por Enrique Morales, cuando en la hacienda había esclavos para hacerlo, y además por ocho pesos, cuando de ordinario costaba 22 reales (APDC, 1795-1797, f. 203). Asimismo, el padre Visitador cuestionaba que se cobraran 78 días de pan por separado, cuando al mismo tiempo se tasaba una partida del gasto de mantención completa, y que exigiera 19 pesos de renta como procurador, cuando las Constituciones de la Orden estipulaban que dichas comisiones no eran empleos remunerables. Además, le exigía explicar por qué en sus escritos "[hablaba] con tanta licencia y sin respeto, del recto proceder y justificada conducta del Muy Reverendo Padre Maestro Fr. Manuel Ruiz” (APDC, 1795-1797, f. $203 v)$.

En su respuesta, fray Tomás López admitió haber sacado el libro del depósito, aunque diciendo que fue solo temporalmente, pues según él luego lo restituyó completo a su lugar. Frente a cada una de las dudas por las inconsistencias de los pagos, dio diversos justificantes, siempre remitiendo como prueba a las cuentas originales extraviadas. Afirmaba además que en la hacienda no había esclavo competente para conducir el casabe, pues "Josecito" se mantuvo la mayor parte ocupado en "cuidar de los caballos del comisionado (Tornería) y traerles yerba" (APDC, 1795-1797, f. 204) ${ }^{28}$. El padre López dijo también que si tasó por separado el pan fue porque en el gasto de manutención se incluía no solo la suya, sino también la de los esclavos que lo acompańaban; asimismo, que reclamaba el pago de su procuraduría, porque se acostumbraba en el Convento de Cartagena dar "a los Procuradores cincuenta pesos, fuera de los zapatos de cada mes" (APDC, 1795-1797, f. 204v). Sobre el tono irreverente de sus mensajes, se excusó diciendo que nunca lo hizo refiriéndose al padre Ruiz, "sino contra unos religiosos que hablaron de su conducta" (APDC, 1795-1797, f. 204v).

No contento con las explicaciones de fray Tomás, ese mismo día el padre Pontón le pidió al Prior indagar entre los frailes que fueron testigos de la entrega de las cuentas originales, los motivos que tuvo fray Manuel Ruiz para no aceptarlas y las expresiones que hizo en orden a dicho asunto. Preguntados los padres fray Bernardo Medina, presidente de novicios, el depositario fray Mariano Acero y el notario del Convento fray Manuel Sánchez, estos respondieron que el padre Maestro Ruiz había dicho que "no las pasaba [las cuentas ${ }^{29}$ ] porque estaban muy malas, enredadas y confusas y que en [ellas] el dicho Padre López alcanzaba el gasto al recibo" (APDC,

28 Pieza 23. Respuesta de fray Tomás López al cuestionario del padre visitador, 24 de mayo de 1797. 29 La aclaración es de los autores. 
1795-1797, f. 205) ${ }^{30}$. Además, afirmaron haber oído decir al padre Ruiz que fray Tomás "le había ofrecido cuarenta pesos para que le solapase las cuentas" (APDC, 1795-1797, f. 205v).

A estas imputaciones se sumó la entrega por parte de "algunas personas que miran el celo de Dios y de la Religión”, de un “instrumento” (un documento) con una lista de individuos del sitio del Palmar de la Candelaria (APDC, 1795-1797, ff. 209-209v) ${ }^{31}$, quienes figuraban en él como deudores del padre López por cantidades de ropa que les vendió al fiado. Además de las firmas de un tal Francisco Antonio Orozco, que hacía de cajero, varios de los cobros y abonos tenían la letra de fray Tomás y estaban respaldados con su firma. En carta del 26 de mayo de 1797, el padre Pontón, invocando nuevamente "el precepto formal de santa obediencia", le pidió al fraile mencionado decir si la lista se la presentaron a él, "como principal dueño de las ropas, y si el apunte de los cobros [era] de su puño y letra" (APDC, 1795-1797, ff. 208-208v) ${ }^{32}$.

Al mismo tiempo, considerando que el trato y comercio de ropas de Castilla por parte de un religioso de Santo Domingo era "un delito y ofensa de Dios y de la Religión, por contra el voto de pobreza” (APDC, 1795-1797, f. 210) 33 el padre Pontón ordenó a fray Agustín Sánchez viajar nuevamente al Palmar, tomar informaciones ante un juez sobre si era o no cierto aquel asunto e informar al padre López de la necesidad de presentarse cuanto antes al Convento.

En cumplimento de su encargo, fray Agustín le solicitó a Miguel José Jiménez, alcalde pedáneo del partido donde ocurrieron los hechos, averiguar si había sido público el trato de géneros y efectos por parte del padre López. Interrogados varios de los vecinos, todos testificaron la veracidad de tales transacciones y que, aunque al principio la venta la hizo un mozo de nombre

30 Pieza 24. Carta de fray José María Pontón, lector en Sagrada Teología y examinador sinodal y visitador de ambas costas, al padre provincial fray Julián Barreto, [en la cual le solicita] interrogar algunos religiosos del Convento de Cartagena sobre los motivos por los que el prior Manuel Ruiz no aprobó las cuentas entregadas por fray Tomás López sobre su comisión en Sábalos y Santa Cruz, 24 de mayo de 1797.

31 Pieza 27. Lista general de los individuos de este sitio del palmar, que son deudores de las cantidades de ropa que les he vendido al fiado. Firman fray Tomás López y Francisco Antonio Orozco.

32 Pieza 26. Carta del padre visitador fray José María Pontón a fray Tomás López, [en la cual pide] verificar la autenticidad de una lista de cobros por ropas, en la [que] este figuraba como propietario, 26 de mayo de 1797.

33 Pieza 28. Carta del visitador fray José María Pontón ordenándole a fray Agustín Sánchez tomar informaciones ante un juez sobre la conducta de fray Tomás López, y mandando a este último a presentarse en el Convento, 12 de mayo de 1797. 
Francisco, a pocos días el propio padre Tomás se encargó del negocio (APDC, 1795-1797, ff. $211-211 v)^{34}$.

Vistas las evidencias y testimonios, el padre Pontón dictó un auto por el que suspendió al padre López de confesar y decir misa, y le ordenó presentarse ante él el 9 de mayo. Además, declaró reprobadas e ilegítimas las cuentas de la comisión de Sábalos. Tres días más tarde, sin que aún se verificara el regreso del fraile, el visitador extendió un nuevo llamado, en el cual le advertía que si in continenti no se presentaba al Convento "se le [aplicarían] las penas y se [tomarían] las más serias providencias, para que el padre (Tomás) no [abusara] de la benignidad con que hasta [entonces] se le [había] tratado" (APDC, 1795-1797, f. 212) ${ }^{35}$.

Como último recurso, el padre López arguyó no haberse trasladado a Cartagena por sus múltiples enfermedades, aunque fray Agustín ya se había adelantado a decir que "estaba bueno y sano" y además diciendo misa, pese a estar suspendido en la provisión de los sacramentos.

Una vez en el Convento, el padre Tomás admitió que la lista por la que se había suscitado su regreso no tenía ninguna alteración, y que efectivamente sí recibía cuentas de Francisco Orozco. Admitida la imputación, el visitador fray José María Pontón dictó un decreto el 29 de mayo de 1797, en el cual compendió todas las faltas que expresaban "la ninguna fidelidad con que el padre Tomás López se [había] portado" (APDC, 1795-1797, f. 216) ${ }^{36}$. A propósito de haberle cargado al Convento una cuenta como procurador y otro por el pan que consumió, habiendo decreto expreso que prohibía tales obvenciones, incurrió "en las penas de propietario, según lo ordenado en el capítulo de Valladolid” (APDC, 1795-1797, f. 216v). También, por no haber hecho caso al auto del padre Ruiz, por el que se le suspendía de la administración de curatos, "en las penas de inobediente", delito "más visible porque sacó las cuentas originales del depósito y se [vio] claramente la pertinencia en ocultarlas" (APDC, 1795-1797, f. 217). Sobre la ligereza y violencia con la que hablaba del padre Ruiz en sus misivas, y "aunque fuera contra otros religiosos", se le reprendió severamente por expresarse "en papeles auténticos con desenfreno

34 Pieza 29. Carta de fray Agustín Sánchez a don Miguel José Jiménez, alcalde pedáneo del Palmar de la candelaria, solicitándole dar información sobre la conducta de fray Tomás López, 26 de mayo de 1797.

35 Pieza 30. Carta de fray José María Pontón a fray Agustín Sánchez, en la cual le ordena a fray Tomás López presentarse inmediatamente al Convento, 12 de mayo de 1797.

36 Pieza 33. Decreto del visitador fray José María Pontón acerca del caso de fray Tomás López. Cartagena, mayo 29 de 1797. 
y expresiones ajenas de la modestia religiosa" (APDC, 1795-1797, f. 217v) ${ }^{37}$. Además, incidió en las faltas de "infiel administrador y falso declarante", pues luego trascendió que durante la comisión de Sábalos "hizo varias cobranzas de derechos parroquiales, casamientos, entierros, etc." (APDC, 1795-1797, f. 218v), sin tener la autorización para hacerlo y sin haber reportado nunca tales desembolsos. Finalmente, vista la ya mencionada lista de deudas y cobros de ropa, era incontestable que fungió "como mercader, tratante o negociante de géneros de Castilla y demás vendibles, con descrédito del hábito y conocido desprecio de los preceptos, leyes y estatutos que [prohibían] a los clérigos el comercio" (APDC, 1795-1797, f. 218v).

Cumplida la diligencia de notificación durante la cual se leyó el decreto en "voz clara y entendible" delante del resto de la comunidad, se determinó que "el padre Tomás permaneciera recluso y por el mismo hecho no pudiere con motivo alguno salir a curato para obviar de esta suerte los males que se le [imputaban]" (APDC, 1795-1797, f. 218v). Mientras tanto, la causa se envió a consulta al Definitorio del Capítulo Provincial para que se determinase lo que se hallare por conveniente.

Pero quizá este no fuera el primer caso en el que se cernían sospechas sobre la gestión de un religioso. Al menos en tres documentos se deja entrever que el prior y vicario provincial en San José durante 1786, el padre José Antonio Pontón (quien no es el mismo visitador del mismo apellido, pero de nombre José María que se menciona en la causa contra fray Tomás López y en otros pasajes de este libro), pudo incurrir en las faltas de "infiel administrador" y comerciante, además de haber retenido ilegítimamente documentación del archivo. Tras dejar el priorato de Cartagena, su sucesor en la silla, el padre Pedro José Rossi, encontró cargadas al Convento dos partidas de egresos del padre Pontón: una de 270 pesos por los gastos de su "venida" a Cartagena y otra por 300 que se pidieron prestados a don Juan Núnez para sufragar un viaje a Santafé. Según el padre Rossi, estos 570 pesos excedían por mucho los límites que dictaban la prudencia y la práctica regular, no solo porque apenas ejerció el cargo por poco más de un año, sino principalmente porque a los priores de San José "cuando [subían] a capitulo Provincial solamente [les daban] cien pesos para ida y vuelta" (APDC, 1787b, f. 23). El nuevo prior aseveraba además que su predecesor había incurrido en tan crecidos gastos, aún a sabiendas de la pobreza del Claustro y del deteriorado estado de muchos de los techos y paredes, sin que a la fecha él mismo no tuviera "arbitrio" alguno para remediar las averías. Al ser compelido para que devolviera a su dueño los 300 pesos tomados en préstamo para

37 Según parece esta no era la primera vez que fray Tomás incurría en esa falta, pues en el decreto se rememora también cuando habló "[...] contra el honor y crédito del muy reverendo Padre prelado Fray Pablo González, sacando sin facultad ni derecho alguno declaraciones de negros y otras gentes viles, imputándole graves y feos delitos" (APDC, 1795-1797, f. 217v). 
auspiciar la "subida" del padre Pontón, fray Pedro José le encareció en una carta al padre Francisco de la Guelga persuadir al padre Provincial de "dejar quieto ese negocio" por ser mucha la penuria del Convento, o de lo contrario se vería en la necesidad de llegar al "extremo [de] hacer notorio en Santafé lo que está oculto y, acuerdo justicia, justificar precisamente contra el honor de Pontón” (APDC, 1787b, f. 24).

Según parece, un mes después llegó la noticia al Convento de que el padre Pontón estaba gravemente enfermo, ante lo cual el padre Rossi escribió nuevamente:

por acá hay noticias fatales de la enfermedad del Revendo Padre Lector Fr. José Antonio Pontón y como en este mundo somos de casta de muertos, suplico a V. P. M. R. (el padre de la Guelga) y trate con arte de recoger todos mis papeles, que no se yo con qué fin cargó con ellos y aun habiéndole escrito sobre este particular nada me ha contestado [...] también ocurre que con motivo de haber sido yo el Vicario durante su ausencia por el capítulo provincial, ajustadas mis cuentas salí a alcanzar al convento en ciento y siete pesos los cuales yo no pedí ni mencioné para nada y ahora encuentro en el libro de gasto puesta de puńo del dicho Padre Lector esta partida: "dimos al Reverendo Padre Fr. Pedro Rossi 107 pesos en que alcanzó al convento", que yo no he recibido nada: con que si Vuestra Persona Muy Reverenda ve el cuento mal parado de que haya de fallecer, interésese en acordarle este asunto para descargo de su conciencia y háblele al alma para que los entregue o que a lo menos los declare. Ello acerca de que del Priorato que obtuvo de este convento tiene infinitos cargos y puedo decir que el de mi plata es el menor (APDC, 1787b, f. 25).

A estas insinuaciones de desfalcos y despilfarros por parte del padre Pontón en la gestión del priorato, se sumó la posible implicación como tratante de mercaderías. En carta de mayo de 1789, entre otras novedades del Convento, le informan al provincial fray Juan José Rojas que recientemente habían "cogido en Albornoz un contrabando en el terreno del Lector Pontón y se lo achacan a él y aun corre que lo descaminaron yendo de Albornoz para Maates en su marcha a Santafé. Vea Usted Vuestra Merced Reverendísima cómo se vive por aquí y la propensión al comercio que se tiene" (APDC, 1789d, f. 26v).

\section{El "pecado original” de Cartagena}

Es necesario decir que la propensión a la trata en la que se vieron inculpados algunos de los regulares de San José se enmarca en uno de los aspectos socioeconómicos más distintivos de 
la historia de Cartagena durante el período colonial: el contrabando. Aunque originalmente este fenómeno estuvo marcado por la salida clandestina o no declarada de oro y plata, para el siglo XVIII casi todos los géneros o mercaderías de Europa que se consumían en el territorio neogranadino eran introducidos de forma irregular.

En Cartagena, pero también en prácticamente todo el litoral Caribe ${ }^{38}$, esa economía ilegal llegó a predominar de tal manera que "todos los sectores de la sociedad - la burocracia, las fuerzas militares, el clero, los comerciantes y los pobres- participaron en ella" (Grahn, 2005, p. 24). El contrabando sustentaba no solo las grandes fortunas de las élites económicas, sino que aún en lo más ínfimo de su menudeo se convirtió en un auténtico instrumento de sobrevivencia para las clases populares. Por ello, para algunos no es exagerado afirmar que "fue el fenómeno central de la economía y la sociedad, conformando, además, una forma de vida y un conjunto de valores" (Múnera, 2008, p. 81) ${ }^{39}$. Como dijera el Guardamayor del puerto en 1721, estaba tan generalizado que era prácticamente "el pecado original del lugar".

Varios factores contribuyen a explicar el arraigo de esta práctica en Cartagena y su provincia. Las contiendas en las que se vio implicada España a lo largo del siglo XVIII (como la guerra de sucesión a comienzos de la primera década de la centuria o los diversos conflictos con otras potencias europeas) interrumpían por largos periodos el comercio entre la Metrópoli y sus colonias, hecho que obligaba a los habitantes a buscar otros medios para abastecerse de los bienes más esenciales, especialmente harina, ropa, vino y herramientas de trabajo. También los asedios y sitios de piratas y filibusteros de los que fue objeto la ciudad en varias oportunidades impedían la llegada de las flotas y además dejaban seriamente dañadas las fuentes de la economía local. A todo

38 Aunque se considera contrabando la entrada y salida de productos sin los respectivos partes y sin pagar los aranceles de ley, entre el tráfico de Cartagena y el de las demás ciudades de la Provincia (especialmente Santa Marta y Riohacha, militarmente menos protegidas) existieron algunos matices. En efecto, mientras en la primera los principales artículos de exportación (legal e ilegal) fueron oro y plata, en las segundas los productos de la tierra (como la carne, los cueros, la sal, el palo de tinte, etc.) fueron los principales artículos de intercambio. Los comerciantes ingleses, franceses y holandeses tenían además en esta región la complicidad de los indios (Colmenares, 1994, p. 70).

39 Vale precisar que, a juicio de varios autores, el contrabando está todavía por abordarse desde una perspectiva más cuantitativa (con todos los desafíos documentales que esto implica); es decir, sopesando sus cifras y alcances reales, independientemente de los actores que se vieron involucrados en él, pues siendo muchos de ellos altos funcionarios reales o miembros de las familias más importantes, esto ha contribuido a que la historiografía sobre el tema esté impregnada de cierto efectismo. 
esto se sumaba que la propia España nunca tuvo una vocación productora ni exportadora sólida, lo que mantenía unos niveles de trato comercial con las Indias bastante exiguos ${ }^{40}$.

Los "derechos de asiento" concedidos por España para regularizar la trata negrera, en su orden, a Portugal, Francia e Inglaterra, significaron la apertura de uno de los principales flujos del tráfico ilícito, pues solapados en los embarques de esclavos siempre venían mercancías ${ }^{41}$. Las condiciones geográficas y topográficas de la ciudad y de toda la costa Caribe neogranadina (las cuales hacían muy difíciles los controles) y la probada connivencia y corrupción de funcionarios de todos los rangos $^{42}$ también proporcionaron condiciones ideales para la extensión del contrabando.

Por su enorme trascendencia y perjuicios, la eliminación del comercio ilegal en las costas de la Nueva Granada constituyó una de las preocupaciones más recurrentes de la administración borbónica. En pro de contener sus efectos desbordados, la Corona dictó varias disposiciones a

40 Según señala María del Carmen Borrego, la endémica incapacidad española para surtir de manufacturas sus posesiones indianas contribuyó a naturalizar el comercio ilegal. A principios del siglo XVIII, la ciudad aún no se había recuperado de las "estrecheces" provocadas por el ataque del Barón Pointis en 1697 (al que siguieron malas cosechas y plagas de langosta), y España estaba enfrascada en una coyuntura de confrontación internacional (lo cual trajo alzas en los tributos para financiar el conflicto). En medio de esta situación, solamente hasta 1713 fondeó en el puerto de Cartagena una flota de 16 navíos con 3573 toneladas, la cual ya no regresó al año siguiente. Así, un tráfico tan errático y limitado hizo que el "socorrido contrabando" se convirtiera para muchos en el único medio de sobrevivencia (Borrego, 2010, p. 446).

41 Por ejemplo, el monopolio del tráfico negrero concedido por un periodo de 30 años a la South Sea Company en 1713 (otra de las concesiones a los ingleses tras la guerra de sucesión) desbordó el contrabando que los ingleses operaban desde Jamaica. Al respecto, Dionisio de Alcedo y Herrera en su Aviso Histórico dijo: “[...] se consiguió una ventaja: la de ascender a contrabandistas de formas más o menos aceptables las numerosas hordas de piratas que, con nombre de filibusteros y bucaneros infestaban aquellas regiones, y la de acrecentar el expolio de España con un carácter legal" (citado por Colmenares, 1989a, p. 200).

$42 \mathrm{Al}$ asumir don Antonio de la Pedrosa y Guerrero el título de primer virrey de la Nueva Granada en 1719, encontró que el gobernador y los funcionarios de la Tesorería, coaligados con varios comerciantes, manipulaban los reportes de entrada para rebajar los aranceles a menos de la mitad, ahorros que luego se repartían en partes iguales entre todos. Estos mismos empleados incrementaban los reportes de decomisos, pues las leyes les permitían reclamar una comisión equivalente al valor de hasta una sexta parte de lo confiscado. Incluso, algunos se apropiaban de parte de los cargamentos, tal como verificó el virrey Pedrosa en el caso de Luis de Biquendi, quien siendo comisionado para valorar el contenido del buque francés El Gran San Ramón, reportó mercaderías por valor de 42000 pesos, cuando en realidad las había por un total de 114.400 (Grahn, 2005, p. 27). 
lo largo del siglo XVIII, entre ellas la sanción de indultos, la dotación de guardacostas y otros cuerpos especializados, y principalmente, la creación del tercer virreinato de América ${ }^{43}$.

A pesar de estas medidas, para el final del régimen colonial, quizá exacerbado por nuevos conflictos bélicos que ocupaban la mayor parte de los esfuerzos y recursos de la Corona, sumado su propio caos y desorden administrativo, el contrabando señoreaba casi sin control en toda la región.

\section{El pan de los pobres}

El servicio de los pobres a través de colectas y donaciones era una ocupación habitual de los frailes en la Colonia. En muchos de los viajeros recién llegados de Europa dejó una vívida impresión el hecho de ver hordas de mendigos y menesterosos apostados en las puertas de los conventos a la espera de un plato de comida, algún ajiaco de "turmas" en las ciudades más frías o, como en Cartagena, una sopa de casabe o pan de mandioca. Sin embargo, en la segunda mitad del siglo XVIII, en el Convento San José este ramo se encontraba bastante desatendido. Tal como veremos más adelante al hablar de los egresos e ingresos de los conventuales dominicanos en Cartagena, en las cuentas y relaciones prácticamente no figuran descargos en este sentido.

Dicha omisión fue advertida por el padre visitador Buenaventura y Castillo en la inspección de 1788, hecho que suscitó un llamado de atención a los superiores del Claustro por considerársele otra forma de relajación de la disciplina conventual. Para emendar la situación, el visitador ordenó

43 Entre 1710 y 1713 , ante la presunción de que indistintamente todos los "comerciantes de carrera" estaban vinculados al contrabando, se otorgó un indulto al cual se acogieron de forma voluntaria muchos de los negociantes más prestigiosos o dueños de los cargos más honoríficos. Entre ellos destacan "los maestros de campo Agustín de Londoño — uno de los comerciantes más ricos de Santa Fe - y José Tafur de Valenzuela —quien había administrado la real Hacienda de Santa Marta - (Colmenares, 1986, p. 138). Entre 1732 y 1737, se establecieron flotillas de guardacostas, se apostaron guardas en varios sitios estratégicos del litoral, así como otros refuerzos terrestres, marítimos o combinados. A pesar de lo onerosa que resultó la nueva estrategia para combatir el contrabando, en términos generales fue completamente infructuosa (Roca, 2003, p. 28). La Corona también introdujo amplias reformas administrativas con la intención de mejorar y vigorizar el gobierno en la Nueva Granada y contener el tráfico ilegal. Esto llevó a la primera creación del Virreinato de la Nueva Granada en 1719, institución que tuvo una efímera existencia (disolviéndose apenas cuatro años después), por su demostrada incapacidad de reprimir el contrabando y porque, al contrario, intensificó el papel de la corrupción en la administración pública. Aunque el Virreinato se estableció de nuevo (esta vez de forma permanente) en 1739, según se deduce de los informes de los virreyes y otros

gobernantes civiles, en el caso de Cartagena sus medidas "apenas lograron debilitar marginalmente la corrupción enraizada en la economía política de la ciudad” (Grahn, 2005, p. 24). 
que los Padres Predicadores de San José "[llevaran] todos los días a una de las cárceles de comer a los presos, para lo [cual se mandó] que los hermanos conversos (alternándose por semanas) [cargaran] después de la mesa segunda su mochila o canasto de pan de trigo o de otra especie, [presidiendo] a los esclavos o concertados que llevasen la refección". Y agrega: "prevenimos que los religiosos de la obediencia de Santo Domingo [deben tratar] siempre a los pobres como en quienes se ve la más viva imagen de Jesucristo" (APDC, 1788b, f. 5).

Si bien la falta de diligencia en el socorro de los pobres podría justificarse por las propias estrecheces y limitaciones económicas a las que se vieron enfrentados los conventuales de Cartagena, su inercia difiere notablemente con la situación de los dominicos en Tunja, quienes repartían a manera de limosna varios de los productos obtenidos de sus haciendas, tal como consta en varios informes de la época. Por ejemplo, el cura párroco interino del pueblo de Chiriví ponderaba el hecho de que los padres del Convento tunjano no desperdiciaban nada y antes bien "[distribuían] entre los pobres gran parte de sus cosechas, [haciendo] sementeras por separado y surtiendo las carnicerías con ganados", de tal manera "que todos los pobres de dicho pueblo y los de [aquel] valle, [eran] amparados y socorridos por estos religiosos” (Báez, s. f., p. 147, citado por Alzate, 2012).

La continencia de los dominicos de San José en la entrega de limosnas a los pobres y mendigos, también contrastaba con la célebre caridad de la sociedad cartagenera. Según la Relación Histórica del Viage a la América Meridional, escrita por Antonio de Ulloa y Jorge Juan en 1748, como la ciudad era destino de "gentes aventureras" en busca de fortuna (muchas de las cuales caían gravemente enfermas por el influjo de la atmósfera del trópico), no era extraño ver europeos en total desamparo ${ }^{44}$. En estos casos, refieren los cronistas, "[brillaba] en los naturales

44 La presencia de contingentes de blancos pobres no era un fenómeno extraño en la sociedad neogranadina. En el caso de Cartagena y otros lugares de la costa caribeña, si bien es cierto que la presencia mayoritaria de los negros definió la dinámica social, siendo en palabras de los viajeros citados "las únicas personas que se [podían ver] en Cartagena y en las estancias y los pueblos", junto a ellos creció también una población blanca "pobre y miserable", que prefería vagar por la ciudad porque "ya [fueran] criollos o chapetones, [desdeńaban] tal denigrante ocupación (el trabajo manual) queriendo trabajar en nada que [fuera] menos que comerciar [...]" (citado por Múnera, 2008, p. 95). Vale la pena resaltar que en contraste a la nutrida base social conformada por negros, mulatos y otras gradaciones de color o "castas" que les seguían, lo cual confirma la vocación como enclave esclavista de la ciudad en el siglo XVIII parece abolido por completo el componente indio del entramado social de Cartagena. En efecto, mientras los negros y sus cruces "constituían la fuerza de trabajo de las haciendas de los alrededores, trabajaban como artesanos y se ocupaban del resto de oficios menores de una ciudad portuaria y castrense" como esta, los blancos, además del grupo de pobres y "venidos a menos" ya nombrados, estaban constituidos por una minoría de 
de Cartagena sin excepción de calidad o Gerarquía [sic], la Virtud de la Caridad", especialmente entre las mujeres, llegando incluso las negras y mulatas pobres a "[recogerlos] y [llevarlos] a sus casas, donde los [asistían] y [curaban] a su costa, con tanto carińo y puntualidad como si tuviesen una preciosa obligación de ello, y al que [moría] le [hacían] enterrar de limosna y aun le [mandaban] a decir alguna misa" (citado por Lemaitre, 1983 [vol. 2], p. 245). Lo mismo ponderaban "en cuanto a la caridad de la Mugeres y gente blanca; [siendo] en todas sus especies [de] genios obsequiosos y agradables en extremo, reluciendo con más particularidad en el femenino Sexo, a proporción que suele ser más natural [en él] la Compassión [sic] y el Agrado" (citado por Lemaitre, 1983 [vol. 2], p. 246).

\section{Funerales y sepulturas}

La honra a los muertos como praxis sacramental regía regularmente las ocupaciones de los conventuales en Cartagena. Las vigilias, los responsos y los funerales y demás ceremoniales para pedir misericordia a Dios a nombre de los difuntos, eran actividades casi cotidianas. Además de los oficios espirituales y piadosos, las honras fúnebres, particularmente la adjudicación de los sepulcros, cumplían también una función estratégica (casi política), que les permitió a los padres del Convento San José mediar su relación con el clero secular, con las autoridades civiles de la ciudad y sobre todo con los benefactores del Claustro.

Las funciones de las comunidades religiosas en los entierros y misas de difuntos estaban determinadas en gran parte por las devociones personales y familiares de los fieles, así como por las relaciones políticas y económicas que los particulares mantenían con los conventos. En el caso del Convento San José, la adoración a la imagen de Nuestra Señora del Rosario atraía a su capilla a numerosos creyentes, muchos de los cuales solicitaban (en vida o en sus testamentos) ser sepultados en dicho altar. Desde luego, tal distinción estuvo reservada en primer lugar a los padres de la Orden, seguidos de otros dignatarios civiles y eclesiásticos. En algunos casos, los bienhechores de las obras y fundaciones de los dominicos también tuvieron prelación en la

los "nacidos en España”, quienes controlaban el comercio, y los criollos o "blancos de la tierra", la pequeña aristocracia local dedicada en su gran mayoría a manejar los intereses de la tierra, siendo dueños de grandes estancias (Múnera, 2008, p. 96). 
repartición de las criptas ${ }^{45}$. Por esta razón, al elevar sus peticiones a las autoridades conventuales, los solicitantes empezaban por enumerar y ensalzar sus ofrendas y donativos, con el fin de mover a su favor la decisión de los padres dominicanos.

Tal fue el caso de la viuda Petrona Teresa Padilla, vecina de Cartagena, quien en su testimonio - en el cual solicita una sepultura en la capilla del Rosario en 1788 - afirma haber contribuido de diversas maneras desde 1733 a fomentar y sostener el culto a la Virgen. Entre otras limosnas y actos de piedad, la señora Padilla "franqueó" por muchos años el incienso para las misas, así como un "palio de holán con sus respectivos encajes” para las procesiones. También se preciaba de haber citado "la devoción de varias señoras para que destinasen algún estipendio para una corona de oro que se hizo a Nuestra Seńora del Rosario" (APDC, 1788a, f. 230) y de haber repartido en varias oportunidades papeletas para otras colectas y suscripciones. Asimismo, recientemente había donado "veinte y cinco pesos para [hacerle] un vestido con botones de oro para el Niño Dios" (APDC, 1788a, f. 230v). A cambio de "la gracia de formar un sepulcro en la Capilla para su entierro y el de su familia”, la viuda comprometía a sus sucesores a reparar anualmente las bóvedas y a "contribuir a la limosna acostumbrada por todos los demás fieles que gozaban el beneficio de sepultura" (APDC, 1788a, f. 231) ${ }^{46}$.

En algunas situaciones, los padres del Convento decidían por sí mismos conceder aquella gracia, principalmente para retribuir a sus benefactores más notorios. En dicho evento radicaban ante un notario una escritura de donación, en la cual se consignaban las motivaciones de tal dádiva, así como las obligaciones que adquirían el beneficiario y sus deudos. Entre otros casos, podemos citar el de don Manuel Escobar, a quien los frailes de Cartagena quisieron "remunerarle tantos obsequios, servicios, limosnas y actos de piedad con que había acreditado su mucha devoción” (APDC, 1795,

45 Vale aclarar que según las excavaciones arqueológicas adelantadas durante la restauración del Claustro de Cartagena en 2000, se evidenció que el privilegio jerárquico que prevalecía al momento de permitir enterrar personas en las iglesias y conventos de regulares, tuvo que ceder ante ciertas contingencias epidémicas y sanitarias. Los hallazgos de varias tumbas en los corredores del Convento, muchas de ellas colectivas, ocupadas por cuerpos de nińos de diversas edades, así lo confirman. El hecho de que estos entierros estuvieran encalados (medida usada en la Colonia para evitar la propagación de miasmas infecciosos), sin ningún tipo de ajuar funerario y que las fechas de los decesos se ubicaran alrededor del segundo cuarto del siglo XVII (cuando según el historial epidemiológico de la ciudad cundieron al menos dos contagios significativos, uno de tifo y otro de fiebre amarilla), hace pensar que ante la urgencia de las pandemias, el claustro tuvo que oficiar como cementerio de la población criolla y mestiza (Plata, 2003, p. 117 y ss.).

46 Es este caso, “atendiendo al mérito y devoción de la suplicante”, fray Pablo González conceptuó positivamente la petición de dońa Petrona. 
f. 92) ${ }^{47}$, asignándole un espacio para su sepultura en la capilla del Rosario. En sus consideraciones, los conventuales razonaban que el culto agenciado por don Manuel, especialmente el estímulo al sacramento de la misa, veneraba "la Majestad Divina y [honraba] las cenizas de los finados y la sagrada incruenta hostia, verdadera representación de la santísima vida, pasión y muerte del redentor Jesucristo" (APDC, 1795, f. 93). El "sacramento del altar", al que tanto había contribuido la familia Escobar, servía además para refrendar "el odio a las cavernas infernales y sus infelices e ingratos habitadores, [aliviar] las almas del purgatorio y confesarse verdaderos siervos de Dios" (APDC, 1795, f. 93v).

Vistos los frutos espirituales de la misa, y siempre que el beneficiario y sus legatarios se comprometieran "en cada un ańo a la celebración de misas cantadas, sepultura cubierta y ofrenda correspondiente a favor de vivos y difuntos, presentes y futuros" (APDC, 1795, f. 93v), los padres del Convento San José manifestaban no tener "embarazo en que se le concediesen al expresado Don Manuel de Escobar, su mujer, hijos, nietos y demás descendientes de los susodichos, de afinidad y consanguinidad habidos legítimamente, sin limitación de tiempo, la sepultura en la capilla de la mencionada imagen" (APDC, 1795, f. 93v) ${ }^{48}$.

En algunas ocasiones, además de la gracia de la sepultura, los padres se comprometían a oficiar misas y plegarias especiales para premiar a sus benefactores. Por ejemplo, el regidor y alférez Real de la ciudad de Cartagena, don Manuel José de Escobar (hijo del personaje del mismo nombre que acabamos de referenciar) ofreció en contra prestación a las misas que los religiosos dominicos pudieran decir a su muerte mandar hacer tres misas por cada religioso difunto. "Atendiendo a la singular benevolencia y piadoso afecto de dicho Señor a la sagrada religión de Santo Domingo", los superiores de la Orden declararon "obligados a todos los religiosos de [la] Provincia, a hacer por [él] en su fin y muerte los mismos sufragios que por cualquier otro Religioso de ella, diciendo cada sacerdote tres misas" (APDC, 1795, f. 102).

Además de las ceremonias ofrecidas, el regidor Escobar donó también tres mil ladrillos toscos y quince carros de cal para la reedificación del Convento (materiales cuyo costo ascendía a 74 pesos), más un donativo de 26 pesos en plata. Ante la cuantía de la limosna (100 pesos en total), los superiores de la Orden manifestaron su reconocimiento y gratitud, ordenándole al prior del Convento de Cartagena (y a quienes le sucedieran en el cargo) que llegado el fallecimiento de don Manuel se practicaran sus honras y sufragios según su voluntad.

47 Entre otras de las ofrendas de don Manuel, se destaca el haber mandado fundir la campana mayor de la iglesia.

48 Un hijo de Manuel Escobar, del mismo nombre de su padre, pidió más adelante que se le permitiera ampliar un poco el terreno donado, para poder construir unas bóvedas. 
Entre otras distinciones y privilegios, el Regidor le pidió a los dominicos que si llegase a caer gravemente enfermo, se le "hiciere rogativa con las campanas", y llegado el caso de estar irremediablemente "próximo a fenecer, se le tocarán agonías". También que le "franquearan el religioso o religiosos que fueren de su devoción para confesarle y ayudarle a bien morir” (APDC, 1795, f. 103). Tras espirar, el cuerpo de don Manuel debía ser conducido al Convento de San José por "quatro hermanos conversos y la demás compañía que deberá venir con luces en las manos acompañándole y rezando los salmos, misereres o de profundis hasta ponerlo en la sala de capítulo". Allí, "su defunto [sic] cuerpo" debía ser velado por toda la comunidad "con la misma exactitud que con un Padre Maestro": el cuerpo amortajado con hábito entero (dado por el Convento), con capa o capilla negra encima y conducido en las mismas andas o ataúd usados para los frailes. Una vez puesto en el sepulcro, debía haber misa cantada y vigilia en el Convento dominicano, pero con asistencia de las comunidades religiosas de San Francisco, San Agustín, San Juan de Dios, San Diego y Nuestra Señora de las Mercedes. Durante los nueve días siguientes a la defunción, se debían poner en la tumba doce hachas y doce velas de libra, y hacer misa, vigilia y responso diario con redoble de campanas (APDC, 1795, f. 103v) ${ }^{49}$. Los religiosos de Santo Domingo accedieron a todos estos compromisos, aunque advirtieron que las velas serían de media libra (pues el Convento carecía de las otras) y que el donante por ser secular no se podía enterrar en las bóvedas de los religiosos, ya que las constituciones prohibían que se mezclaran los cuerpos de los unos con los otros ${ }^{50}$.

Por la importancia dada a los ritos funerarios entre la sociedad neogranadina del siglo XVIII, muchos entierros dieron lugar a no pocas disputas. Tanto entre las órdenes regulares, como entre estas y el clero secular, se suscitaron algunas desavenencias, principalmente cuando el difunto ostentaba alguna dignidad especial. En el Convento San José se recordaba, por ejemplo, la agria disputa que sostuvieron en 1725 por la restitución del cuerpo del Chantre de la Catedral ${ }^{51}$, Luis Ignacio Melgarejo ${ }^{52}$.

49 Todas estas recomendaciones debían guardarse aún si don Manuel fallecía estando fuera de Cartagena, en cuyo caso, notificado el Prior por los herederos o albaceas, éste debía hacer lo pertinente para cumplir con el ceremonial.

50 Para sortear este inconveniente, los padres destinaron un espacio para la bóveda en la pared que quedaba justo debajo del púlpito de la iglesia.

51 Según las canonjías con las cuales se creó el obispado de Cartagena, el chantre de la iglesia catedral — quien debía saber canto llano- tenía como función "cantar en el facistol (atril) y enseñar a cantar a los sirvientes" (APDC, s. f., f. 3).

52 Según parece, a usanza de la época el padre Melgarejo, siendo clérigo secular dispuso en su testamento ante notario público su voluntad de ser enterrado en el Convento regular de los dominicos. 
Empero, quizá el asunto más espinoso era la conciliación de dos fueros distintos (el de seculares y regulares) al momento de oficiar funerales. Durante el último cuarto del siglo (entre 1779 y 1794), los dominicos y otras órdenes conventuales de Cartagena se enfrentaron con los curas parroquiales de la ciudad. Según los regulares, los religiosos seculares penetraban ilegítimamente a los claustros con el pretexto de acompañar a los difuntos, habiendo cédulas, breves y otros documentos pontificios y reales que separaban expresamente las jurisdicciones de unos y otros.

El choque de fueros sobrevenía cuando moría un parroquiano que en sus testamentarias hubiera dispuesto su sepultura en la iglesia o capilla de algún convento. Durante la agonía, e inmediatamente después de la muerte, los primeros oficios espirituales estaban a cargo del padre de la parroquia del difunto. Este consolaba a la familia y oficiaba los primeros responsos y letanías. Enseguida, portando la cruz, estandartes y bandera de la parroquia, acompañaba el cortejo fúnebre hasta entregarle el cuerpo a los conventuales, quienes salían a recibirlo en comunidad. El ritual, en teoría sencillo y armonioso se tornó turbulento, pues mientras los regulares sostenían que la transferencia del cuerpo debía darse en el atrio del templo, los seculares defendían "la práctica inmemorial" de conducirlo hasta la mitad de la iglesia, donde el cura párroco tenia prelación para hacer el último responso.

Los primeros en manifestar su disgusto fueron los dominicos. Según denuncias del doctor Lázaro José Blanco, cura teniente de la catedral de Cartagena, durante dos sepelios fueron notorios los desplantes y ultrajes de los religiosos de la Orden de Predicadores, pues en uno el diácono del Convento se negó a recibir el hisopo de mano del sacristán de la parroquia, y en otro ni siquiera salieron a recibirlo (APDC, 1779-1794, f. 10).

\footnotetext{
Aunque esta práctica (el entierro en los claustros de personas distintas a los miembros de la comunidad) estaba amparada por varias bulas apostólicas y por las leyes de Indias, tras el funeral del religioso las autoridades del Cabildo de la ciudad (seguramente presionadas por la curia secular) pusieron en entre dicho el procedimiento y la autenticidad de la rúbrica, afirmando que no había testigos que lo corroboraran. En el memorial respondiendo a la exigencia de devolver el cadáver del padre Luis Ignacio, el procurador del Convento, fray José Velásquez del Campo, argumentó que la certificación de un notario o escribano público valía como prueba de la voluntad del testador o disponente (APDC, 1725, f. 228). Además, el padre Velásquez elevó una representación a los superiores de la Orden, para que autorizaran al Arcediano y al Tesorero del Convento (quienes asistieron al funeral del Chantre) a presentarse ante el Obispo y certificar que el entierro del padre Melgarejo en la bóveda de san Pedro del templo dominico se había hecho con expresa autorización suya (Archivo General de la Nación (en adelante AGN), 1797, f. 676v).
} 
Por decreto del obispo fueron interrogadas varias personas para que confirmaran o desmintieran las denuncias del padre Blanco. Los declarantes debían explicar también si era cierto o no que en Cartagena se acostumbraba la entrada de los padres seculares a los conventos e iglesias de los regulares a oficiar misas. Entre otros rindieron testimonio los presbíteros Juan Antonio de Herrera, Ventura Echagaray, Guillermo Guillen y Juan Pablo Rodríguez (respectivamente maestro de capilla, sacristán, maestro de sagradas ceremonias y clérigo de menores órdenes de la catedral de Cartagena). También fueron interrogados Domingo Villegas y Miguel de Vanquecel, dos vecinos piadosos asistentes a los sepelios que suscitaron la querella. Aunque casi todos confirmaron las denuncias del padre Blanco con ligeros matices, no hubo una opinión general sobre desde cuándo se permitía a los curas seculares oficiar en los conventos de regulares. Según el padre Herrera, al parecer quien más tiempo llevaba en la ciudad, desde que entró a servir en la Catedral en 1726 había visto guardar el mismo ritual:

En los conventos de regulares de esta ciudad en los entierros que en ellos se han hecho ha salido a recibir la cruz de la parroquia, la (cruz) del convento con sus ciriales, un sacerdote revertido de preste, con sus diácono y subdiácono, y la comunidad o la mayor parte de ella, y dando el Preste la derecha al párroco que recibía llegaban hasta el lugar destinado para cantar el último responso por los ministros que conducían el cadáver, ministrando el religioso subdiácono al párroco para la aspersión el hisopo que recibía de mano del sacristán de la parroquia (APDC, 1779-1794, f. 12).

Ante las versiones recabadas, el doctor Diego Calderón, fiscal de la curia de Cartagena, conceptuó que si bien ordinariamente prevalecían las prerrogativas dadas a los regulares, estas se "limitaban siempre que [hubiese] costumbre inmemorial en contrario", por ser más poderoso que el privilegio "un uso tan antiguo a que no alcanza la memoria del hombre" (APDC, 17791794, f. 16). En vista de ello, para evitar futuros desaires, el obispo dictó un auto el 10 de febrero de 1780, en el cual exhortó a todas las órdenes religiosas a respetar "el pacífico derecho" de los párrocos seculares, de presentarse en los conventos "con su cruz parroquiana, sobrepelliz, capa y estola”, siempre que fueran a oficiar misas de difuntos. Asimismo, ordenó a todos los priores conventuales de la ciudad guardar con "armonía y urbanidad" el orden y disposición usados hasta entonces en las ceremonias fúnebres (APDC, 1779-1794, f. 18) ${ }^{53}$.

53 Esta providencia se notificó al prior José Mariano Adminaorta del Convento de Predicadores, al padre Guardián fray Joaquín Bohórquez del Convento de San Francisco; a José María Conrado, prior del Convento Hospital de San Juan de Dios; a fray Juan de la Cruz, prior del Convento de Agustinos 
A pesar del mandato, apenas un día después de dictado el auto el padre Blanco se quejó de nuevo, esta vez por las faltas de respeto de las que fue víctima en la capilla de la Veracruz del Convento de San Francisco. Según el presbítero, cuando conducía a dicho Claustro el cadáver de un soldado pasado por las armas, el diácono que salió a recibirlo, al igual que el del Convento San José, con gesto "arrogante y temerario" se resistió a tomar el hisopo de manos del sacristán (APDC, 1779-1794, f. 20) ${ }^{54}$.

Aunque el fiscal Calderón quiso atenuar la controversia diciendo que quizá el gesto no se debía a un acto de inobediencia de los regulares de San Francisco, sino a que ignoraban la providencia dictada, en dos oportunidades más los padres del Convento San José desatendieron el orden ceremonial de los sepelios. En palabras del padre Blanco, este gesto ponía en evidencia que los regulares de la ciudad, liderados por los dominicos, se habían propuesto "alterar el estilo y práctica antiquísima [observada] en los entierros, [perturbando] la paz del clero y [disputándole] a la iglesia matriz" (APDC, 1779-1794, f. 24v). Tan caldeados llegaron a estar los ánimos entre las sotanas, que el fiscal del obispado Alonso Blanco de Hermosilla, llegó a decir que el único medio para precaver futuros malentendidos era gravar el ceremonial en tablillas que debían fijarse en todas las sacristías de Cartagena.

Para justificar las actuaciones de los padres predicadores, el prior fray José Antonio Pontón elevó en noviembre de 1786 una representación en la que citó varias bulas, decretos y opiniones de autores según las cuales se debían mantener separadas las jurisdicciones del clero regular y secular, no obstante "la contraria costumbre". Su sucesor en el priorato, el padre fray Pedro José Rossi, fue incluso más allá. No solo quiso demostrar que a los padres seculares les estaba prohibida la entrada a los conventos, sino que reunió testimonios que descubrían que en Cartagena no existía la tal "costumbre inmemorial" en la que se amparaban los curas seculares. Según el padre Rossi, por la década de 1750 los padres parroquiales tomaron por costumbre presentarse a los entierros en los conventos con la cruz y otros estandartes. Al ser compelidos por los regulares para que

Calzados, a fray Juan Hurtado prior de los Recoletos Descalzos, y al Dr. Lázaro José Blanco, quien entabló originalmente la denuncia.

54 Dichos hechos fueron confirmados por los presbíteros Juan Rodríguez, Miguel de Soto y Marcelo de Mesa, capellán de la Real Armada de Cartagena, capellán de coro y capitán de coro de la iglesia catedral, respectivamente. 
no entraran a sus templos, armaban violentos escándalos y griterías, en las que amenazaban con confiscar los cadáveres si no se les permitía el paso ${ }^{55}$.

De esta manera, los casos citados contradecían la afirmación de los presbíteros de que su entrada a las iglesias de regulares, con todos los arreos ceremoniales de la parroquia, era una costumbre inveterada. Esta se había impuesto a la fuerza, pues ante las amenazas de los párrocos de llevarse los cuerpos, y por no contrariar a los dolientes (que desde luego eran benefactores de los conventos), los regulares terminaban aceptando su ingreso. En vista de estos testimonios, el padre Rossi alegó que el privilegio de los regulares concedido por los pontífices seguía vigente, y que por consiguiente era inapropiado y contra derecho el ingreso de curas seculares a sus iglesias.

Ante las evidencias, el 21 de septiembre de 1794 el obispado ordenó a los párrocos —con cierta ironía - seguir la práctica difundida en Santafé: al morir alguna persona, el párroco y sus ministros debían presentarse a la casa del difunto y hacer el ritual romano para preparar el cuerpo y conducirlo por la calle. Al llegar al atrio o altozano de la iglesia donde por su voluntad (o la de sus dolientes) se efectuaría el entierro, el párroco o preste secular debía dar con la mano abierta una bendición al cadáver, "inclinar la cabeza al preste o al prelado de aquella iglesia regular, y de allí mismo dejar el altozano de los regulares, [retirándose] para su parroquial, sin proceder para más adentro de aquella iglesia, ni a otra acción alguna, como que allí no [era] lugar de su jurisdicción ni aun de la diócesis" (APDC, 1779-1794, f. 85).

\section{Nombramientos y traslados}

Como en los demás claustros de regulares, para la asignación de los "destinos" o cargos ocupados por los frailes del Convento San José de Cartagena, se ponían en juego varios factores: desde luego, los méritos personales (estudios, experiencia, trayectoria, conducta, etc.) eran determinantes en muchas de las elecciones; sin embargo, también eran muy importantes las afinidades entre los frailes (espirituales, personales o intelectuales), especialmente con los superiores de la Orden. El padre Rossi, por ejemplo, refiriéndose en una carta a fray Francisco de la Guelga, admitió estar en el priorato por su mediación o recomendación, cuando — con mucha familiaridad— dijo: "Vuestra Persona Muy Reverenda es mi taita y ya que logró si quiera colocarme de Prior, mire

55 El padre Rossi mostró con testigos y documentos que en al menos siete casos (en los conventos de los dominicos, de los franciscanos y de los agustinos) se dio esa entrada de los padres seculares por la fuerza y bajo amenazas de secuestrar al difunto. 
por mi y por este pobre convento haga de cuenta que está en el mismo puesto y defienda este partido y los otros confiados como si se le pasaran directamente" (APDC, 1787b, f. 24).

Muchos de los religiosos pedían que les certificaran por escrito los estudios realizados, así como su desempeño en los distintos cargos en las nóminas de los conventos. Tras su salida de Cartagena, el padre José María Pontón le pidió al prior fray Pablo González que certificara bajo juramento in verbo sacerdotis, tacto pectore et corona, su labor como regente de estudio (APDC, 1793a, f. 14). Igual solicitud elevó fray José Vicente de la Bastida, en cuyo certificado se consignó que, según constaba en el Libro de Estudios de San José, él "bajó del [Convento] de Santafé con patente de Lector en artes para este [Convento] de Cartagena, el año 1799 [...], y el 18 de octubre del mismo año empezó a leer la lógica” (APDC, 1814, f. 147). Asimismo, en 1821 el padre fray Agustín Sánchez le solicitó al padre prior Rafael Alarcón su concepto respecto al cumplimiento de su labor como vicario prior del Convento cartagenero (APDC, 1821, f. 15).

Durante las visitas, inspecciones periódicas (bianuales en algunos casos) para evaluar las cuentas conventuales, el estado de los edificios, los inventarios, etc., también se calificaba el cumplimento de las funciones de los religiosos. Esos testimonios e información compilados por los visitadores favorecían la promoción y los traslados de los padres.

Por ejemplo, en 1758 el padre fray Francisco Villegas, visitador de los conventos y doctrinas de la costa, asentó en su libro de visita unas efusivas felicitaciones a fray Cipriano Pantoja, capellán de Nuestra Señora del Rosario en el templo dominico de Cartagena. Según el padre Villegas, la buena administración de fray Cipriano había reducido el "alcance" del gasto al recibo a apenas cuatro pesos $y$ tres reales ${ }^{56}$. Por el gran adelantamiento de la capellanía en los últimos dos ańos (desde la visita de 1756), fruto de su "fervoroso zelo, ardiente devoción, personal trabajo y solicitud para el culto de dicha soberana Reina", además de "confirmarlo" o ratificarlo en el puesto, fray Francisco le dio "repetidas gracias en nombre de tan divina Señora y de Nuestro Padre Santo Domingo de cuyo soberano patrocinio debe esperar la recompensa en lo espiritual y temporal" (APDC, 1758, f. 1).

En contraste, al revisar las partidas económicas del Convento de la Villa de Tolú, regentado por el padre fray Francisco Amuedo, el visitador Villegas se quejó enérgicamente, pues a pesar

56 Dicho "alcance" era uno de los índices con que se juzgaba el éxito de los religiosos en la administración de las rentas. En efecto, los frailes que gastaban mucho más de lo que recibían eran objeto de reprensiones por su falta de economía, y casi siempre debían mostrar los soportes que explicaran el porqué del saldo negativo. En el caso del padre Pantoja, sus cuentas mostraban unos ingresos por 255 pesos y unos gastos por 359 pesos y tres reales, incluida una partida que le correspondía a él por su capellanía, por valor de 100 pesos, los cuales cedió "a favor de Nuestra Señora". 
de haber tenido unas entradas más notorias que las del Convento de Cartagena, estas eran duplicadas por los gastos ${ }^{57}$. Semejante alcance, dice, "es precedido de la falta de moderación en el gasto ordinario que tiene dicho Reverendo Padre Prior" (APDC, 1758, f. 1v). Y agrega: "gastar en tanta demasía redunda grave daño, pues aquellas limosnas que [gasta] el Prior [Amuedo] en satisfacer los gastos causados en la decencia con que se mantiene, se impondrían (prestarían a interés), cuyos principales existiendo no cerrarían el efecto de sus réditos en adelantamiento del tal convento" (APDC, 1758, f. 2) $)^{58}$.

Para evitar excesos (como los del padre Amuedo) y fomentar la dedicación (como la del padre Pantoja) entre los priores de los conventos, el visitador propuso finalmente rotarlos cada dos años, "de forma que el que fuera buen operario en este, pase a serlo a aquel, y al contrario. Y los que hubieren sido poco zelosos sean traídos al convento de Cartagena a trabajar y servir en los ministerios que gustaren ocuparlos los prelados" (APDC, 1758, f. 2).

El recelo del padre Villegas por el rendimiento y la aplicación de los priores no era fútil. La elección del prior era uno de los ritos de la vida conventual que más suscitaba expectativas, como quiera que de la conducta y el talante del superior dependieran en buena parte los buenos oficios del resto de la comunidad. El procedimiento para designarlo era una consulta conventual, a la cual concurrían los frailes que ocupaban las principales plazas en la administración del Claustro. El vicario In capite, el maestro de novicios, el maestro de estudiantes, el procurador general, el notario, el padre predicador y los padres lectores de Prima, Vísperas, Artes y Cánones se daban cita en alguna de las celdas del Convento para estimar los méritos y cualidades morales de los aspirantes. De la elección del prior de Cartagena en 1775 se conserva el acta de consulta por la cual resultó escogido el padre fray Mariano Admińaorta, quien hasta ese momento se desempeñaba como Lector de Vísperas. Según concluyeron los padres llamados a deliberar en la consulta, el nombramiento recayó en fray Mariano por todos los votos (a excepción del suyo), por no tener "los feos lunares de excomulgado público, de condenado sentencialmente ni privado por fallo de voz activa y pasiva, sino antes bien por tener a más de su notoria religiosidad, grande conducta, policía, honradez, agilidad e interés, en una palabra todas las condiciones que piden los sagrados cánones para un completo Prelado" (APDC, 1775, f. 135v).

57 Desde la última visita (1756), el prior Amuedo reportaba ingresos de 334 pesos y 4 reales, y unos gastos de 612 pesos y 6 reales.

58 El visitador le ordenó finalmente a fray Francisco “conmensurar” sus gastos, ciñéndose estrictamente a los 177 pesos anuales asignados por la Orden para la manutención de cada prior conventual. 
Luego de la designación por las autoridades conventuales, la decisión se notificaba al provincial para que llamara a consulta de provincia, donde por votación secreta se ratificaba o no la elección. En el primer caso se le libraba patente de aprobación, con la cual se posesionaba del cargo, mandándose "que como a hijos de obediencia, él [aceptara] y los conventuales lo [recibieran]"; en el segundo se mandaba a repetir la elección (APDC, 1808, f. 6).

Los nombramientos en las órdenes religiosas no escaparon a las incidencias de la transición a la República. En Cartagena la Suprema Junta de Gobierno establecida desde el 13 de agosto de 1810, se reservó el derecho a revisar el contenido de las patentes, las ternas y otros mandatos que llegasen al Convento Dominico de la ciudad, "por si tuvieren algún exceso de jurisdicción, alteración o novedad, que [pudiera] trastornar o ceder en detrimento de los súbditos" (APDC, 1811, f. 235). La medida, dictada en función de la facultad de "tuición y poder económico" con la que se invistió la autoridad de la Junta, buscaba preservar "todos aquellos inconvenientes que se pudieran suscitar por la dependencia de los conventos y comunidades religiosas de su distrito, de los Prelados y extrańas autoridades de ajenas Provincias" (APDC, 1811, f. 235).

Este recelo seguramente se debía a las tensas relaciones entre las distintas juntas de gobierno que surgieron en la Nueva Granada tras el grito de independencia de 1810. En el caso de la Junta cartagenera fueron particularmente recurrentes las disputas con los gobiernos de Santafé y de Mompox. Según el padre Enrique Báez, la pretensión de la Suprema Junta Patriótica era emancipar el Convento de Cartagena de los del interior, llegando incluso a entrometerse en la elección de prior. Cuando fue designado para ese cargo el padre fray José de Jesús Saavedra ${ }^{59}$, hijo del Convento de Tunja, "por la sola razón de no ser conocido en Cartagena" se le tildó de "sospechoso contra la República” (Báez, s. f. [vol. 6], p. 117). La Junta logró finalmente invalidar la elección y hacer nombrar en su lugar al cartagenero fray Felipe Buitrago, quien de todas formas denegó la designación.

59 El padre Juan José de Jesús Saavedra y Miranda era natural de Suaita (entonces Provincia de Tunja, actual departamento de Santander). Ejerció el priorato en Chiquinquirá entre 1831 y 1834, y en Bogotá entre 1839 y 1842 . Fue elegido provincial en dos oportunidades, en los periodos 1826-1830 y 1842-1846. Él y los padres fray Marcelino y fray Isidro Saavedra eran tíos maternos de fray Buenaventura García Saavedra, uno de los cuatro padres restauradores de la Orden a comienzos del siglo XX (García, 2011, p. 18). 


\section{Dos priores para la misma silla}

En 1793, tras verificarse uno de tantos procesos de nombramiento de prior, la comunidad dominicana de Cartagena vivió una crisis de dimensiones cismáticas: dos frailes (y sus respectivas camarillas de simpatizantes) se levantaron reclamando para sí la silla prioral. Más allá de los bemoles de la confrontación, el episodio nos muestra la importancia que revestía para la vida monacal la elección del superior. En aquella oportunidad, siguiendo el ceremonial que describimos más atrás, resultó elegido el padre fray José María Pontón. Sin embargo, cuando todavía no llegaba la confirmación de los superiores provinciales de Santafé, un auto Real anuló la designación por considerársele poco idóneo para el cargo. Según una comunicación del provincial al Rey, el padre electo impugnó esta destitución en un tono "ajeno a la obediencia de un prelado y lleno de despotismo", lo cual dio pie a que fuera castigado quitándole los cargos de "capellán del Rosario y Regente del Convento" (APDC, 1794, f. 6).

A pesar de las sanciones, el padre Pontón se resistió aceptar la decisión, ejerciendo por su cuenta la función de prior. Dicha conducta violaba varios principios inmemoriales de la Orden, consignados en sus constituciones y en otros documentos papales. Por un lado, su apelación era improcedente, pues al no haber recibido la confirmación del priorato nunca tuvo posesión de él, ni adquirió derechos, ni obediencia de sus hermanos. Además, su airado reclamo era también inviable, porque las constituciones prohibían a los religiosos dominicos entablar pleitos o litigios contra sus superiores $^{60}$. Más grave aún, al estar ejerciendo un priorato espurio por no haber

$60 \mathrm{Al}$ respecto, el padre Provincial dice: "la constitución en los mismos lugares citados le prohíbe formar litigio y reducir el punto (el de su posesión) a contestación, y mucho más la apelación que la misma constitución expresamente la prohíbe con pena de absolución de oficio fundada en un Breve de Bonifacio VIII y dos de Julio II, que son tan expresos en la materia que no dejan el menor efugio al religioso profeso de Santo Domingo para poder ocurrir ni a los Prelados Superiores de su religión ni mucho menos a otros tribunales" (APDC, 1794, ff. 6v-7). Sobre la inconveniencia de que los regulares concurrieran libremente a juicios u otros litigios, en una carta al Rey de España el padre Barreto dirá también: "Si para este y otros preceptos verbales que corresponden a nuestro gobierno y Prelacía para el mejor servicio interior de nuestros Conventos, fuera necesario hacer Proceso, [faltarían] manos y papel y se destruyera enteramente la obediencia y gobierno monástico. Este (el proceso) y otros ejemplares de igual naturaleza, son perjudicialísimos a una profesión, instituto y constituciones, dá por tierra con el Gobierno interior de los claustros, que desde luego fuera mejor cerrarlos, que permitirlo; porque si a cada precepto del Prelado había de haber recursos y actuación Judicial, se volvería una confusión la obediencia profesada; los Prelados tendrían atadas las manos por su Gobierno, y los súbditos quedarían sin Superior Eclesiástico ni Seglar; lo que no ha de permitir la potestad de un Soberano, quien como a sus vasallos, debe hacer ver a los que han 
recibido patente y habérsele quitado toda superioridad (la regencia del Convento), el padre Pontón carecía por completo de jurisdicción espiritual. Por esta razón, el Provincial se lamenta ante el Monarca:

Considere Vuestra Alteza el miserable estado en que se halla en la actualidad el convento de Cartagena, sin prelado, porque legítimo no lo tiene, con un cisma parcial entre los religiosos, que unos lo reconocerán por superior y otros no [...] Yo no sé con qué conciencia estará usando [el padre Pontón] de las llaves de la Iglesia para con sus súbditos imaginarios, absolviendo y ligando con censuras y dando facultad de absolver a los individuos de su comunidad, causando una ruina espiritual irreparable en las almas y exponiendo los sacramentos a una viciosa nulidad (APDC, 1794, f. 7).

De esta manera, al no ejercer en derecho su cargo, y dividida la opinión entre quienes lo reconocían como prior y los que no, a juicio del autor de la carta fray José María se convirtió en una amenaza para el bienestar espiritual del Convento San José. La situación vino a agravarse aún más cuando el Definitorio del Capítulo Provincial, queriendo poner fin al asunto, desde Santafé nombró como prior al padre fray Manuel Ruiz, "sujeto de notorias prendas y religiosidad". Aunque el padre Ruiz aceptó la designación, no pudo tomar posesión de su cargo por el conato de "tropelía" que se dio entre los frailes de Cartagena. Abrumado por la gravedad de la situación, el Provincial advierte:

Por cualquier parte que se mire su recurso (el del padre Pontón) es constante que no se le hace la menor violencia y él es el que nos hace fuerza a los prelados y a los súbditos con su falta de subordinación, con su mal ejemplo, con la cisma que ha introducido y con no dejar obrar a sus prelados ni ejercer sus facultades (APDC, 1794, f. 7v) ${ }^{61}$.

tomado el estado Religioso que observen la Regla y Constituciones que profesan, y no vivan con una total independencia sin subordinación” (citado por Báez, s. f. [vol. 6], p. 96).

$61 \mathrm{Al}$ parecer, para preservar el honor de los frailes a los provinciales no les estaba permitido revelar los motivos para reprobar las elecciones. Sin embargo, el autor de la carta dice que ante la tenaz insistencia del padre Pontón expresa contra su voluntad que el motivo legal para no aprobar su designación como prior en Cartagena fue el no poder ser juntamente prior y lector. 
Para conjurar la rebelión, el provincial le pidió al Rey respaldar el nombramiento de fray Manuel, dictando una real provisión auxiliatoria de la Audiencia de Santafé, de tal manera que ni al padre Pontón ni a ninguno de los frailes que le respaldaban les quedara duda de la legitimidad de su título. Finalmente, depuesta la desmedida pretensión de fray José María de hacer prevalecer su elección, el provincial Julián Barreto decidió — por recomendación del Monarca— que la sanción para aquel no fuera "ponerle preso ni mandarlo presentar en calidad de tal, ni si quiera despojarlo de la Cátedra de Teología, [sino] señalarle otra conventualidad distinta de la de Cartagena" (citado por Báez, s. f. [vol. 6], p. 96), lo cual se confirmó con su traslado al Convento Santo Domingo de Mompox.

\section{De conventuales a párrocos}

La tenencia y administración de parroquias e iglesias fuera del Convento fue una práctica regular de los frailes cartageneros. Con diversos intervalos, durante la Colonia los dominicos tuvieron a su cargo las doctrinas y parroquias de San Andrés, Morroa, Piojó, Malambo, Gaira, San Jacinto, Tolú, Tubará, Mompox, Sitionuevo, Usiacurí, El Palmar, Colosó, Simití, Badillos y Simaña (Ariza, 1992 [vol. 1], pp. 261 y 264). Desde luego, quienes tomaban dichos oficios eran los frailes ordenados como sacerdotes, aquellos que por derecho podían administrar los sacramentos. Del Convento de Cartagena se conserva la patente conferida a fray Juan José Rojas para "confesar todo género de personas y también monjas, absolver de reservados y la facultad de habilitar incestuosos". Según reza la licencia (cuyo original está en latín), el religioso que recibía esta aprobación podía "[oír] de penitencia a todas las personas de uno y otros sexo, que con él tuvieren devoción de confesarse, absolviéndolas si las hallare bien dispuestas e instruidas en los misterios de [la] Fe, de todos y cualesquiera pecados, sin reserva alguna exceptuada la herejía mixta" (APDC, 1797, ff. 232-233v). Asimismo, el sacerdote recibía la facultad de "absolver y dispensar de cualquier suspensión e irregularidad, exceptuadas las [originadas] de la bigamia verdadera, del homicidio voluntario y también para [habilitar] a los conyugues impedidos para el uso del matrimonio" (APDC, 1797, ff. 232-233v) ${ }^{62}$.

62 Fray Juan José Rojas también fungió en Cartagena como maestro de novicios, cargo del que hizo dejación argumentando que "las ocupaciones de la catedra a [su] cuidado, la continua asistencia al confesionario y otras religiosas ocupaciones a que [se veía] obligado por la escaces [sic] de operarios" del Convento, no le dejaban "tiempo para asistir continuamente y desempeñar, conforme [debía y deseaba], 
Por los acontecimientos de la Guerra de Independencia, muchos más religiosos regulares tuvieron que ejercer dichas funciones. Las campañas de 1815 y 1821 dejaron vacantes la mayor parte de las parroquias de la provincia de Cartagena. Durante la Pacificación, por ejemplo, algunos de los poblados fueron abandonados y arrasados por sus propios habitantes, de tal forma que no sirvieran para el abasto de las tropas enemigas. Tras el advenimiento de la República, por la notable falta de curas seculares el obispado de Cartagena solicitó a los superiores de las órdenes conventuales de Santo Domingo y San Francisco expedir licencias a sus religiosos sacerdotes emplazados en Cartagena, para que pudieran salir a administrar los curatos abandonados. De esta forma vemos a frailes dominicos ejerciendo incluso como capellanes del Monasterio de la Popa (fundación de los padres agustinos), destino encargado a fray Eugenio José de Luis, quien recibió el mandato de restablecer el culto a la imagen milagrosa de la Virgen de la Candelaria y reedificar el monasterio en el emblemático cerro (APDC, 1823b, f. 257v). Entre otros, también se conserva el pedido del vicario del partido de Simití, para que "fray Juan José García Villavicencio, del orden de Santo Domingo, pasara a encargarse de la parroquia de Badillos, por no tener sacerdote que la administrara" (APDC, 1824a, f. 223v).

La ocupación de las parroquias por los regulares implicó sensibles bajas en las nóminas de los claustros, justamente en un momento en que las autoridades civiles empezaban a fraguar un plan de supresión de los conventos que no albergaran a por lo menos ocho religiosos ${ }^{63}$.

el magisterio de servicios sino que antes bien [se había] visto obligado a faltar muchas veces al Noviciado y dejar de acompañar a los Hermanos en los actos de la Comunidad". "Para que no [padeciera] la enseńanza de los jóvenes detrimento alguno", el religioso pidió al Padre Visitador y Vicario Provincial le admitiera la renuncia de dicho oficio, a lo cual le respondieron afirmativamente (AGN, 1792, f. 877).

63 La ley del patronato eclesiástico (28 de julio de 1824) sancionó que era potestad del Congreso de la República "permitir o no la fundación de nuevos monasterios y hospitales; suprimir los existentes si lo [considerara] útil, conveniente y oportuno, y dar destino a sus rentas, etc." (Posada, 1865). En el marco de estas facultades, en abril de 1826 el Congreso ordenó dar ejecución a la ley de supresión de conventos menores, sancionada desde el 21 de julio del "año II" (1821). La medida buscaba "procurar la conservación de la disciplina monástica y el fomento de la instrucción pública”, declarando suspendidos todos los conventos "que no tuvieren ocho religiosos sacerdotes de continua y permanente residencia dentro de sus claustros". Los edificios y bienes raíces y muebles de los conventos suprimidos debían adaptarse y/o adjudicarse para servir como colegios, o en su defecto "enajenarse al contado o a censo por los gobernadores de las respectivas provincias" (Senado y Cámara de Representantes, Ley de supresión de conventos menores del 7 de abril de 1826], pp. 1-2). Esta ley fue abolida por Bolívar mediante decreto, "por haber causado mucho disgusto a los pueblos", los cuales "recibían grandes beneficios espirituales de los religiosos que vivían en los conventos suprimidos, [predicando] y [administrando] los sacramentos a los fieles, siendo muy activos auxiliares de los párrocos" (Bolívar, Decreto del Poder Ejecutivo del 10 de julio de 1828, pp. 1-2). 
En mayo de 1826, en atención "al enorme perjuicio a la religión por el desamparo en el que [quedaron] muchas parroquias, retirándose los ministros encargados de su pasto espiritual”, los provinciales de las órdenes dominicana y franciscana, expresaron su disposición a que los sacerdotes de sus conventos siguieran administrando espiritualmente aquellos sitios hasta ser relevados por presbíteros seculares, siempre que a los frailes se les siguiera reconociendo como conventuales (APDC, 1826, f. 32). En otras palabras, por el bienestar de la feligresía los regulares aceptaban la residencia temporal de algunos de sus miembros en las parroquias de la región, pero sin que esto fuera a representar una purga en sus nóminas de religiosos.

Para agosto de 1827, la mayor parte de los religiosos dominicos del Convento de Cartagena continuaba haciendo las veces de párrocos. Sin embargo, la posibilidad cierta de que la desocupación del Claustro sirviera como pretexto para su supresión y confiscación por parte de las autoridades civiles llevó a la comunidad a reclamar el reintegro y la refacción de la edificación, de tal forma que se pudiera volver a recibir a los frailes en clausura. Los dominicos exigían que se levantaran todas las tapias derribadas para habilitar el Convento como cuartel, y "que los dos oficiales [existentes] en él [desocuparan] la pieza que [habitaban], a fin de poder reducir a sus claustros a los sacerdotes religiosos" (APDC, 1827, f. 224) que por entonces regresaban a esa capital. Las autoridades de la intendencia manifestaron que dicha restitución solo podía verificarse en el momento en que estuvieran "todos los religiosos reunidos y el Padre prior del convento [viniera] a ponerse a la cabeza de la comunidad" (APDC, 1827, f. 224v).

Además de justificar la ocupación del Claustro por la falta de frailes que lo habitaran, también argüían que su traslado al servicio y administración espiritual de varias parroquias de la diócesis no se había producido por su mandato, y que hasta la fecha "ni uno solo, ni uno siquiera" de estos religiosos había solicitado separarse de su curato para reducirse a clausura. En suma, que ni la Intendencia los había removido del Convento, ni los frailes daban señal de querer volver a su antigua condición. Los pocos que se encontraban en Cartagena, agregan, "han venido con licencias unos para medicinarse y otros a practicar diligencias propias". Finalmente, afirman que si los religiosos dominicos no querían volver a su conventualidad era quizá porque habían "[pasado] a otros beneficios más pingües o más análogos a su constitución física” (APDC, 1827, f. 224v).

\section{Enfermedades y salubridad}

Tal como demandara fray Tomás López en el alegato contra sus superiores, era obligación de la comunidad velar por la salud de los frailes. Por esa razón, como se podrá ver al hablar de la 
economía conventual, la curación de las enfermedades constituía uno de los ramos del gobierno del Claustro, figurando en todas las relaciones de gastos y pagos el estipendio anual de un médico y la contrata con un boticario para suministrar las medicinas ${ }^{64}$.

Dadas las condiciones sanitarias de la ciudad, no es de extrañar que la preocupación por el cuidado de la salud fuera un imperativo. Cartagena, como otros puertos del Caribe, era célebre por la suciedad, el clima malsano y las endemias recurrentes. En 1789, don Joaquín de Cańaveral y Ponce, recién llegado en calidad de comandante general de mar y tierra, y gobernador político y militar de la ciudad y Provincia de Cartagena, quedó sorprendido por la mugre e inmundicias que pululaban en las calles, aún en las más principales. Por ello, en su auto El deber de vivir ordenadamente para obedecer al Rey, titulado en inmejorable armonía con el espíritu de las Luces y la naciente noción de policía, reservó varios de los artículos al tema de la salubridad ${ }^{65}$.

Al parecer, en Cartagena la conjunción de la suciedad y la atmósfera perniciosa afectaba especialmente a los europeos recién llegados, siendo frecuentes altos índices de mortalidad entre ellos $^{66}$. La temperie de las costas americanas ubicadas en la zona tórrida era particularmente temida, pues se consideraba que su disposición topográfica, las oscilaciones del clima, "con un calor sofocativo de día y de noche una temperatura demasiado fresca”, la abundancia de las

64 Por ejemplo, en los informes de 1771 y 1790, el pago del médico y el contrato con el boticario era de 50 pesos cada uno (APDC, 1771, f. 18, y APDC, 1790, f. 16). Para 1799, el gasto de botica se incrementó a 208 pesos y el de asistencia y cuidado de los enfermos a 150 (APDC, 1799, f. 20).

65 Entre otros asuntos, el gobernador ordenó que todos los vecinos de cualesquier condición tuvieran "las puertas y pertenencias de sus casas y calles aseadas, bien barridas, compuestas y enladrilladas sus haceras [sic] o calzadas". Asimismo, prohibió que se arrojaran "basuras, ojas [sic] o inmundicias en las calles y plazas, ni tampoco en las playas, sino precisamente en el mar o lagunas de la Escollera sacándolas por la Puerta de Santo Domingo o por los Boquetes destinados a este fin en el recinto de la Muralla", imponiendo penas a los contraventores de hasta cuatro pesos, o en su defecto ocho días de cárcel para los que no pudieran pagar esa suma. En el auto se enfatizaba especialmente la inconveniencia de que se derramaran aguas en las calles por las ventanas, puertas y balcones, no solo por "los lodazales y pantanos que las [ponían] asquerosas sino también porque con sus vapores y alitos [sic] corrompidos [infectaban] la salud causando muchas enfermedades". Para remediar el problema de las aguas sucias, el gobernador dio un plazo no mayor a un mes para que todos los propietarios instalaran en sus viviendas sumideros y letrinas donde vaciar los "vasos inmundos" (Cańaveral, [1789] 1992, pp. 122-123).

66 Aunque son conocidos varios casos de funcionarios civiles y eclesiásticos que ni siquiera alcanzaron a tomar posesión de sus cargos, la mortalidad era particularmente alta entre las tropas. Según el historiador Carlos Marchena, entre 1699 y 1799 llegaron a Cartagena 13 unidades peninsulares con un total de 6667 soldados y oficiales, de los que solamente regresaron 1551. Los demás, 2706 se quedaron en la plaza y 2410 se reportaron como perdidos, la gran mayoría por muerte (Marchena, 1982, p. 363). 
lluvias en ciertas estaciones y la vecindad a tierras sin cultivar, cubiertas de bosques y aguas estancadas, producían "de continuo las fiebres pútridas y malignas de difícil curación” (González, 1805 , p. 507) ${ }^{67}$.

Los viajeros figuraban a los americanos meridionales como seres "pálidos, enfermizos, descarnados y cadavéricos, de modo que más se podrían tener por unos espectros ambulantes que por hombres" (Brown, 1800, p. 33). Según muchos facultativos de la época, en Cartagena los rigores del clima forzaban una transpiración de los cuerpos tan desmedida y continua, que todos los habitantes se mantenían débiles, con aspecto enfermizo y con una característica "inercia en todos sus discursos y operaciones" (Brown, 1888, p. 33). Y aunque los que llegaban de Europa mantenían el semblante de robustez y los colores vivos por espacio de tres o cuatro meses, pasado ese tiempo, "a fuerza de sudar" adquirían la contextura "de los naturales del país, [su] color tan pálido y quebrado como si empezaran a convalecer de alguna grave enfermedad, y cierta floxedad y desaliento en todas sus acciones y movimientos, hasta en el hablar" (Estala, 1797, p. 192).

Por lo general se admitía la existencia de dos tipos de enfermedades: por un lado, aquellas que sobrevenían a los europeos recién llegados, llamadas popularmente "chapetonadas"; por el otro, las que eran comunes en todas las personas. Las de la primera especie se consideraban muy peligrosas dada la elevada "mortandad y destrucción de gran parte de la gente [de] las armadas o navíos de Europa". Dichos males eran casi siempre "de tan corta duración (tres o cuatro días), en cuyo término o morían o quedaban libres del peligro" (Estala, 1797, p. 194).

Uno de los padecimientos atribuidos al clima era la clorosis, enfermedad cuyo principal síntoma era la palidez de la cara, acompañada de una astenia o debilidad universal. Los médicos acuñaron específicamente la denominación "clorosis de Cartagena de Indias", para hacer referencia a la debilidad fruto de "los grandes calores y la abundante transpiración y sudor de sus habitantes" (Ballano, 1806, p. 65). Además del decaimiento generalizado, la clorosis generaba sed insaciable, tristeza, pereza y, especialmente entre las mujeres, "un apetito insaciable por comer yeso y tierra" (Ballano, 1806, p. 65) ${ }^{68}$.

67 Para precaver el peligro el doctor González recomendaba "fondear siempre a la mayor distancia que [fuera] posible de estas tierras enfermizas, [evitando] las exhalaciones pútridas que el ayre [sic] [arrastraba] consigo" (González, 1805, p. 507).

68 Según el doctor Ballano, "la cura genérica se [dirigía] a fortalecer y dar tono vital a las partes endebles para lo cual, además de una dieta analéptica (reconstituyente) y el ejercicio moderado, se recomendaban los tónicos ferruginosos, como la quina y la multitud de plantas tónicas y corroborantes (sedantes)”. 
Otro de los morbos endémicos en la ciudad era el vómito prieto (fiebre amarilla), enfermedad que acometía en los puertos de la América meridional y septentrional, particularmente en los de Veracruz, Cartagena, Portovelo y Panamá. El médico cartagenero Juan José Gastelbondo, quien ejerció en el Hospital de San Juan de Dios, observó que el vómito negro solamente asaltaba a los europeos "recienvenidos" y no a los habitantes de la ciudad, atribuyendo las causas "a la mutación de clima y a los alimentos de menos sustancia y jugo que los de España, de que resultaba mala quilificación ${ }^{69}$; [así como] al producto de humores heterogéneos, aires viciosos y corrompidos, que depositados en el estómago y mesclados (sic) con el suco pancreático, adquirían una nueva fermentación de color negro" (Villalba, 1803, p. 129) ${ }^{70}$.

Asimismo, entre los naturales y vecinos de la ciudad y la provincia de Cartagena eran frecuentes los casos de lepra o mal de San Lázaro. Aunque algunos médicos atribuían la abundancia de esa enfermedad al consumo habitual de carne de puerco (como según parece acontecía en las mesas cartageneras); una gran mayoría consideraba que se originaba por la peculiar cualidad del clima.

Paradójicamente, las precarias condiciones sanitarias y la asiduidad de ciertos morbos hacían que en Cartagena, a diferencia del resto del Nuevo Reino de Granada, la falta de médicos fuera quizá menos ostensible. Por la permanente confluencia de militares, galeotes y esclavos, y el ir y venir de viajeros y mercaderías desde y hacia España y las provincias del interior, la ciudad adquirió gran importancia estratégica como puerto comercial y asiento regular de las tropas comisionadas para la defensa de las flotas. Esto hizo de la presencia de los galenos una necesidad impostergable.

A Cartagena, como a otros lugares del Virreinato, llegaron los hermanos hospitalarios de San Juan de Dios, quienes recibían en sus nosocomios a la población pobre así fuera con fines más

69 La quilificación "o mutación de los alimentos en quilo se hace así: mascado el manjar, y mezclado con saliva, baja por el esófago al estómago, y el jugo ácido de esta entraña se mezcla, e incorpora con el manjar y le penetra y divide en partes tan pequeńas, que parece ya licor, el cual comprimido por el estómago, se ve obligado a salir por la pilora y entra en los intestinos, en donde encuentra otros dos disolventes, que son la bilis y el jugo pancreático: éstos pues acaban de licuar los alimentos y reducir a licor lo que acaso estaba unido, y así de los intestinos entra lo más sutil que llamamos quilo [...] El fundamento de toda la Medicina, es poner en buen estado la quilificación viciada” (Terreros, 1788, p. 262).

70 En efecto, en las disecciones anatómicas practicadas por Gastelbondo, este "encontró los estómagos y las vejigas llenos de un licor negro, y el intestino duodeno ennegrecido". 
benefactores que médicos ${ }^{71}$. Como vimos en la citada causa contra fray Tomás López, para curar su enfermedad recurrió al religioso de esta Orden fray Mariano García, quien le despachó un recibo por diez pesos y dos reales por las medicinas que le suministró de la botica del hospital, y otro más por ocho pesos correspondientes a las 75 visitas o revisiones que le practicó en el tiempo que duró su padecimiento (APDC, 1795-1797, f. 175) ${ }^{72}$.

En la ciudad también se contaba con la presencia de médicos castrenses, dado el permanente arribo de tropas. Para finales del siglo XVIII, la Corona española reglamentó la asistencia continua de médicos y cirujanos en cada una de las unidades del ejército y la armada. Uno de estos facultativos, Santiago Padilla, cirujano del Batallón de Milicias de Voluntarios Pardos de la Plaza de Cartagena, fue consultado por fray Pedro José Rossi cuando una enfermedad le impidió concurrir al Capítulo Provincial en la capital (APDC, 1789c, f. 139).

Aunque no es muy común, algunos de los documentos (principalmente la correspondencia) dejan entrever la naturaleza de las enfermedades de los frailes del Claustro cartagenero. Por ejemplo, como muchos de los recién llegados a América, fray Juan Christiano le informa desde Cartagena al padre fray Manuel León en Santafé, que aunque no fuera "creíble, cuasi que desde [su llegada] de España [había] estado enfermo, y aún estoy de convalecencia, he caído, vuelto a levantar y vuelto a caer, por ahora creo que quedaré eternamente bueno" (APDC, 1798, f. 28).

Asimismo, por una carta de enero de 1778 sabemos que fray Juan José Rojas padeció largamente "fatiga de calores" (APDC, 1778a, f. 21), quizá una clorosis o debilidad generalizada como la que referenciamos atrás. En este caso, el padre Rojas confió el restablecimiento de su salud a una "cura de espíritu”, encareciéndole a su interlocutor (probablemente un religioso dominico del Convento de Tunja) que "lo pusiera a las plantas de la Señora de Roque Amador"73. Un mes más tarde, el

71 Los hermanos hospitalarios se asentaron en la ciudad desde 1603, tomando bajo su administración el Hospital de San Sebastián. Con el tiempo este plantel empezó a ser reconocido como Hospital de San Juan de Dios. Para finales del siglo XVIII, el San Juan de Cartagena se hallaba en un estado deplorable, como se evidencia en un informe de 1790: "Hallase en el más lastimoso de los estados, por la mala asistencia de los enfermos, que consisten en pobres de solemnidad, soldados de tierra y marina, esclavos del Rey y presidiarios, porque sus camas unas son de tabla y otras son de cuero, pero la mayor parte sin colchón ni estera, tocando sus huesos en esos duros lechos y la aflicción y dolores de sus males se hacen más graves por la unión de unos con otros" (citado por Solano, 2005, p. 91).

72 Pieza 5. Recibo de pago a fray Mariano García del Hospital San Juan de Dios, por las medicinas de la botica y las visitas a fray Tomás López del orden de Santo Domingo. Cartagena, 9 de mayo de 1795.

73 Esta imagen de la virgen estaba ubicada en el altar mayor del Monasterio de Predicadores de la ciudad de Tunja. Según las Genealogías de Flórez de Ocariz, era "una imagen de bulto (una talla), de buen 
padre Rojas informó en otra misiva haberse "visto bastantemente quebrantado de suerte que [se vio] obligado a recibir sangrías ${ }^{74 "}$. Y agrega: "he mudado pellejo, me parece que me hallo algo mejor, pero dígale a la Señora de Roque Amador que me haga bueno y me dé salud" (APDC, 1778 b, f. 1v).

El padre prior Pedro Rossi fue acometido de una "fluxión erisipelatosa a las piernas", un absceso que podía sobrevenir luego de una flebotomía por usar una lanceta sucia o mal afilada. Esta dolencia, muy común entre los viejos y valetudinarios, era raramente mortal pero sumamente dolorosa, e impedía además los movimientos por la inflamación de las extremidades ${ }^{75}$. En la mayoría de los casos la afección de la cutis se extendía sobre toda la pierna, apareciendo úlceras con "una materia abundante, tenue y muy acre lo que [ocasionaba] al miembro un dolor intolerable, y cuando se [levantaban] las curaciones despedía un vapor parecido al del agua hirviendo" (Underwood, 1791, p. 115). Según el cirujano que atendió al padre Rossi, habiendo salido de viaje para Santafé, por "el calor del sol la enfermedad le acometió con mucha violencia hasta llegar a exulcerarse (llagarse), en términos que le obligó a regresarse a Cartagena, pues de continuar el camino podía ocasionársele la muerte" (APDC, 1789c, f. 139).

tamaño y hermosura, traída de España por Félix del Castillo, su patrón, y con rótulo en la peaña del escultor que la hizo, de quien ha tomado el apellido, nombrándola el común Nuestra Señora de Roque Amador” (Flórez, 1674, p. 196). Al parecer, la imagen destilaba un bálsamo al que se le atribuían varias propiedades curativas y milagrosas.

74 La sangría o flebotomía consistía en hacer una incisión con una lanceta en alguna de las venas del cuerpo para extraer sangre con fines terapéuticos. Algunos diccionarios médicos de finales del siglo XVIII y principios del XIX, comprenden en la voz sangría todos los mecanismos para evacuar sangre, como la aplicación de sanguijuelas y las escarificaciones o cortes superficiales de la piel. Su uso terapéutico corresponde a la medicina hipocrático-galénica, cuyos preceptos señalan que en las enfermedades inflamatorias, es decir, cuando fuera evidente la "congestión sanguínea", la evacuación de la sangre coadyuvaba a calmar el dolor y aliviar la tensión. Generalmente las sangrías se hacían en las venas de las extremidades o del cuello, especialmente en los dedos de los pies y de las manos, aunque también, según la dolencia o la proximidad del órgano o parte afectada, se practicaba en la frente, las sienes, al lado de la nariz o debajo de la lengua. Su estatuto como práctica era más bien conflictivo, pues tratándose de una operación mecánica se consideraba un procedimiento quirúrgico, aunque como precepto terapéutico, era materia médica. Por derivación se conocía como "sangrador" al individuo que efectuaba la sangría, rol que desempeñaron no solo médicos y cirujanos, sino también barberos y boticarios.

75 Según el saber médico de la época, la terapéutica de esta enfermedad consistía en "aplicaciones de sanguijuelas sobre la parte inflamada, el uso de los emolientes (desinflamatorios), el régimen (la dieta) y las tisanas refrigerantes" (Diccionario, 1823, p. 302). 
En el caso de fray Tomás López, el hermano de San Juan de Dios que le atendió consignó en su recibo que fue requerido para tratarlo por "una enfermedad del escroto", probablemente un edema o un lipoma, afecciones en las que se da una infiltración acuosa del tejido celular de esa parte del cuerpo, la cual produce entumecimiento, hinchazón y dolor. Las causas podían ser un estado de debilidad general, una enfermedad de larga duración, una hemorragia o una contusión (Hurtado, 1823, pp. 446-467) ${ }^{76}$.

Luego de la ocupación de la ciudad por el Ejército Pacificador en 1815, el Convento Dominico fueconvertidoencuartel.Según unacartadel priorfray Mariano Acero, lainsalubridado "pestilencia" por el hacinamiento de las tropas "prendió" entre todos los hermanos —entonces confinados a unas pocas celdas - una "relajación de estómago" que a él especialmente, "por [su] edad de 51 años llena de varios achaques", por poco le cuesta la vida (citado por Báez, s. f. [vol. 6], p. 125). La gravedad de su enfermedad "[lo] puso en términos de ver médico, el cual viendo que no aprovechaban varios remedios que [le] hizo" prescribió la necesidad de que saliese cuanto antes del Convento y se fuera al campo.

Durante su licencia el padre Acero fue nombrado por las autoridades civiles de Cartagena "contralor o mayoral" del Hospital de San Lázaro, recinto donde desde principios del siglo XVIII se confinó a los enfermos de lepra. A pesar de la denominación, aquel era apenas un conjunto de chozas cuya finalidad era aislar a los contagiados del resto de la población ${ }^{77}$. Incluso los enfermos conducidos a él debían llevar consigo sus propiedades muebles para impedir que a través de estos el contagio pasase a otros.

Las réplicas y testimonios de que la lepra estaba cundiendo por el Virreinato ${ }^{78}$ dio lugar a que el leprocomio —ubicado originalmente en el arrabal de Getsemaní - se trasladara a finales del siglo XVIII al sitio de Cantera Vieja o Caño de Loro, donde de todas formas, según la relación

76 Por lo general se curaba con aplicaciones tónicas y el uso de un suspensorio. En casos extremos se recurría a una ablación (extirpación) del tejido comprometido.

77 La práctica de segregar a los leprosos hundía sus raíces en tradiciones medievales. Estos degredos partían de la concepción según la cual la lepra era una enfermedad contagiosa, aunque para algunos médicos también se conjugaban en su aparición factores como la herencia, la alimentación, el clima, la atmosfera y el desaseo (Obregón, 2002, pp. 71, 72).

78 Se decía, por ejemplo, que los lienzos con los que se vestían la mayor parte de los habitantes eran el principal vehículo de la enfermedad, pues estos se producían en el Socorro, región donde al parecer la lepra era muy recurrente (Obregón, 2002, p. 75). 
de Mando del virrey Ezpeleta, siguió siendo un conjunto de bohíos de paja que apenas servía de habitación a los lazarinos ${ }^{79}$.

Durante la pacificación del territorio, el venezolano Francisco Antonio Morales, quien estaba bajo el mando de Morillo, argumentando la política de "Guerra a Muerte" hizo degollar a los leprosos y mandó quemar el Hospital en diciembre de 1815 (Ibáńez, 1891, p. 129) ${ }^{80}$.

La misión de fray Mariano consistió en ayudar a restaurar el Hospital "destruido por la revolución”. En un informe de 1818 al padre Provincial le refiere haber sido nombrado además capellán del leprosorio, así como los avances de las obras. Según relata, se habían construido 20 habitaciones, conformado una "nueva constitución" y dado nombramiento a los nuevos empleados. Además, siguiendo "instrucciones del Rey de España, se había fundado la Junta de Hospital conformada por el Gobernador, un oficial real, presidente de ella, el Obispo, dos revisores y el Escribano del Gobierno". Por entonces, fray Mariano seguía trabajando "en la fábrica de varias oficinas que le [faltaban] y en que cada uno de los empleados [fuera] ejerciendo las funciones correspondientes" (citado por Báez, s. f. [vol. 6], p. 125).

79 El lazareto de Cartagena se sostenía con el pago de los derechos de anclaje de todos los navíos y flotas que fondeaban en el puerto. Sin embargo, los internos pasaban muchas necesidades y escaseces, por lo que se adoptó la práctica de permitirles salir a las calles a mendigar.

80 Además del asesinato de los lazarinos y sus familias, a Morales también se le atribuyen otros crímenes similares, como haber mandado degollar "hasta el número de cuatrocientas personas" entre aquellos que se presentaron ante él al siguiente día de la ocupación de Cartagena, incluidos "hombres sexagenarios, mujeres y niños, pescadores infelices — dice el cronista Arrázola — que ninguna parte podían tener en las ocurrencias políticas". Tras el sitio, como muchos otros claustros de la ciudad el Convento de la Merced fue tomado para cuartel, correspondiéndole a Morales y su hueste ocuparlo. "Era voz común — dice la misma crónicaque en el silencio de sus patios y corredores Morales sacrificó después muchas otras víctimas, que puestas en cepos eran asesinadas a palos por los soldados” (Arrázola, 1963 [vol. 2], pp. 157-158). 


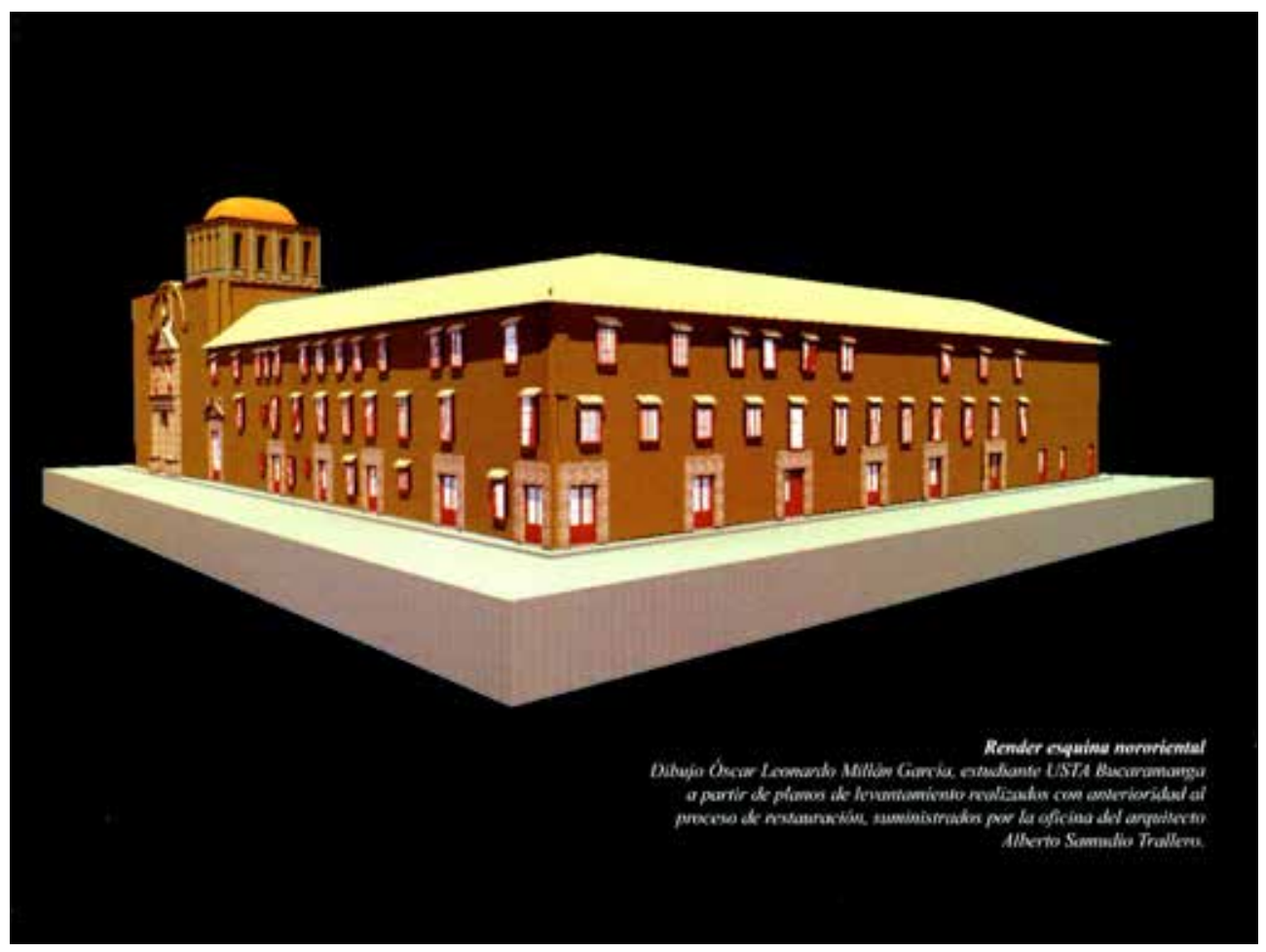

Óscar Millán García. Esquina nororiental del Convento y Templo de San José en Cartagena de Indias. Dibujo. Fuente: William Plata. Conventos dominicanos que construyeron un país. Arquitectura dominicana, fe y sociedad en la Nueva Granada (Colombia) Siglos XVI - XIX, (Bucaramanga: Universidad Santo Tomás, 2010, p. 109). 